\title{
Heterogeneous distribution of pectin and hemicellulose epitopes in the phloem of four hardwood species
}

\author{
Jong Sik Kim ${ }^{1} \cdot$ Geoffrey Daniel ${ }^{1}$
}

Received: 8 July 2017 / Accepted: 6 November 2017 / Published online: 15 November 2017

(c) The Author(s) 2017. This article is an open access publication

\begin{abstract}
Key message Distributional patterns of pectin and hemicellulose epitopes in the phloem of four hardwoods vary between cell types including sieve tube elements, companion cells, parenchyma and sclerenchyma and between tree species.

Abstract Using immunolocalization methods combined with monoclonal antibodies, the distribution of pectin and hemicellulose epitopes was examined in the secondary phloem of two diffuse porous (birch, aspen)- and two ring porous (oak, ash) hardwoods with a focus on sieve tube elements (SEs), companion cells (CCs), axial/ray parenchyma cells, and sclerenchyma cells (sclereids and phloem fibers). In all tree species, rhamnogalacturonan-I (RG-I), homogalacturonan (HG), and xyloglucan epitopes were common in cell walls of SEs, CCs, and axial/ray parenchyma cells. However, the amount of these epitopes varied greatly between cell types and between hardwood species. Apart from aspen, heteroxylan or/and heteromannan epitopes were detected in SEs, but were not detected in CCs and parenchyma cells. With sclerenchyma cells, RG-I, HG, and xyloglucan epitopes were common in compound middle lamellae (CML) of sclereids and phloem fibers. Except for oak, heteromannan epitopes were also detected in CML of sclereids. Distributional patterns of epitopes in CML of birch and ash sclereids varied greatly depending on anatomical structure of CML. Secondary cell walls of sclereids and phloem fibers revealed abundant heteroxylan epitopes, but showed no heteromannan epitopes. Some phloem fibers also showed sparse xyloglucan epitopes in secondary cell walls. Together, results suggest that there are great variations in distributional patterns of pectin and hemicellulose epitopes in hardwood phloem between cell types and between tree species.
\end{abstract}

Keywords Companion cell $\cdot$ Hardwood phloem $\cdot$ Parenchyma cell $\cdot$ Phloem fiber $\cdot$ Sclereid $\cdot$ Sieve tube element

\section{Introduction}

Phloem is the primary transport tissue for photosynthates and signals and regulates a variety of physiological processes from growth to reproduction in plants (Savage et al. 2016). In woody plants, the phloem (secondary) is produced through the activity of vascular cambium and represents

Communicated by M. Zwieniecki.

Electronic supplementary material The online version of this article (https://doi.org/10.1007/s00468-017-1638-z) contains supplementary material, which is available to authorized users.

Geoffrey Daniel

geoffrey.daniel@slu.se

1 Wood Science, Department of Forest Products, Swedish University of Agricultural Sciences, P.O. Box 7008, 75007 Uppsala, Sweden the inner part of bark in a stem. Formation and structure of phloem in a tree stem vary depending on many factors including species, age, and growth conditions (Gričar et al. 2016). With respect to hardwood stem, phloem is composed mainly of sieve tube elements (SEs), companion cells (CCs), axial/ray parenchyma cells, and sclerenchyma cells (fibers and sclereids). SEs are long conduits that are responsible for carbon transport throughout a tree (Savage et al. 2016; van Bel 2003). Metabolic function of SEs is supported by neighboring CCs that are a specialized form of parenchyma cells (Savage et al. 2016; van Bel 2003). Parenchyma cells (axial/ray) are major sites for storage and are responsible for xylem-phloem interactions (Chaffey and Barlow 2001). Sclereids and phloem fibers have thick lignified secondary cell walls and support mechanically the phloem (Zhao and Zhu 2014).

Chemically, hardwood phloem is composed of a variety of components including lignin, polysaccharides, extractives, 
and proteins. Detailed gross chemical analysis of phloem tissue roughly separated from other bark tissues has been reported for hardwood phloem (e.g., Dou et al. 2016; Eyles et al. 2007; Şen et al. 2010; Thornber and Northcote 1961). However, our current understanding of hardwood phloem chemistry at the individual cell level is very poor, since classical wet chemical analysis does not generally allow this type of information due to gross fractionation of entire phloem tissues. It is also a difficult task to separate individual cell types from entire phloem tissues for chemical analysis. In this regard, in situ immunolocalization techniques combined with glycan-directed probes are arguably the best way to obtain chemical information of hardwood phloem at the individual cell level (Lee et al. 2011). Recent developments in glycan-directed probes, such as monoclonal antibodies and carbohydrate binding modules (CBMs), have made possible localization of various cell wall components in plant cell walls without fractionation of plant tissues (e.g., Kim and Daniel 2012a, 2017; Marcus et al. 2008, 2010; Xue et al. 2013). Chemical information on hardwood phloem at the cellular level is primarily important for a better understanding of phloem cell function and development. A detailed understanding of phloem chemistry can also provide a basis for decomposition of hardwood phloem that is currently considered as an important biomass for biorefineries as a part of bark (Dou et al. 2016; Şen et al. 2010).

Apart from vessel-less hardwoods, hardwoods are mainly classified into ring porous, semi-ring porous, and diffuse porous based on the porosity morphology of xylem (IAWA 1989). Since anatomical difference is generally related to difference in frequency of xylem cell types and each cell type has different chemistry of cell walls, the chemistry of hardwood xylem is likely to differ between porous types and wood species. Several previous studies have shown these differences in many hardwood species (e.g., Bodîrlău et al. 2007; Donaldson 2001; Fengel and Grosser 1975; Pettersen 1984). In contrast, differences in phloem chemistry between hardwood species in relation with the porous form in xylem are almost unknown, particularly at the cellular level.

In this study, we investigated occurrence of pectins and hemicelluloses in phloem cells of four hardwoods (two ring porous- and two diffuse porous hardwoods) using immunolocalization methods combined with monoclonal antibodies specific for pectin and hemicellulose epitopes. Results show important variations in distributional patterns of pectin and hemicellulose epitopes in hardwood phloem between cell types and between tree species.

\section{Materials and methods}

\section{Plant materials}

Small sectors were taken from stems $(1.3 \mathrm{~m}$ above ground level) of two mature diffuse porous hardwoods [silver birch (Betula pendula, ca. 27.6 in diameter), European aspen (Populus tremula L., ca. $16.9 \mathrm{~cm}$ in diameter)] and two mature ring porous hardwoods [English oak (Quercus robur L., ca. $20.1 \mathrm{~cm}$ in diameter) and European ash (Fraxinus excelsior, ca. $33.8 \mathrm{~cm}$ in diameter)] grown at a forest site near the campus of the Swedish University of Agricultural Sciences on September 13-16. Sectors were fixed in a mixture of glutaraldehyde and paraformaldehyde and embedded in LR White resin (London Resin Co., Basingstoke, UK) according to procedures described previously (Kim and Daniel 2012a).

\section{Light and fluorescence microscopy}

Lignin distribution in phloem cells was examined using transverse sections (ca. 50-100 $\mu \mathrm{m}$ ) prepared from fresh blocks after staining according to Wiesner and Mäule reaction (Kim and Daniel 2016). Sections were examined using a Leica DMLB light microscope (Wetzlar, Germany) equipped with Infinity X-32 camera (Deltapix, Smorum, Denmark). For immunofluorescence labeling (Kim and Daniel 2012a), semi-thin sections (ca. $1 \mu \mathrm{m}$ ) prepared from embedded blocks were incubated with eight monoclonal antibodies specific for 1,4- $\beta$-galactans (LM5, Jones et al. 1997), 1,5- $\alpha$-arabinans (LM6, Willats et al. 1998), heteroxylans (LM10/LM11, McCartney et al. 2005), xyloglucans (LM15), homogalacturonans (HG, LM19/LM20, Verhertbruggen et al. 2009a, b), or heteromannans (LM21, Marcus et al. 2010) epitopes (PlantProbes, Leeds, UK), followed by incubation with Alexa Fluor 488 (Invitrogen, Oregon, USA). Control sections were incubated with Alexa Fluor 488 only. Sections were examined using a Leica DMRE fluorescence microscope (Wetzlar, Germany) with I3 filter cube (excitation 450-490 nm, emission $>515 \mathrm{~nm}$ ). To detect autofluorescence under UV excitation, some sections were also examined with A filter cube (excitation 340-380 nm, emission $>425 \mathrm{~nm}$ ). Fluorescence images were taken using a Leica DFC 490 digital camera (Heerbrugg, Switzerland). For observations of general anatomy, some serial sections were observed using light microscopy after staining with toluidine blue (Kim and Daniel 2012a).

To study potential effects of pectic HG on detection of hemicellulose epitopes, sections were pre-treated with $0.1 \mathrm{M}$ sodium carbonate ( $\mathrm{pH} 11.4$ ) for $2 \mathrm{~h}$ at room temperature, followed by incubation with $30 \mathrm{U} / \mathrm{ml}$ pectate lyase (Megazyme, Wicklow, Irland) in $50 \mathrm{mM}$ CAPS (3-(cyclohexylamino)1-propanesulfonic acid) buffer (pH 10.0) containing $2 \mathrm{mM}$ 
$\mathrm{CaCl}_{2}$ for $2 \mathrm{~h}$ at room temperature prior to immunofluorescence labeling (Kim and Daniel 2017; Lee and Knox 2014). Equivalent sections were also pre-treated with only sodium carbonate prior to immunofluorescence labeling. Results of immunofluorescence labeling including the enzymatic pretreatment reflect observations on two to three different serial sections of each tree sample.

\section{Transmission electron microscopy (TEM)}

To examine variations in the ultrastructure and distribution of pectin epitopes (homogalacturonans) between compound middle lamellae (CML) of sclereids, birch sclereids were examined using a Philips CM12 TEM (Eindhoven, Netherlands) combined with lignin staining $\left(\mathrm{KMnO}_{4}\right)$ and immunogold labeling (Kim and Daniel 2012a, 2017). Transverse ultrathin sections (ca. $90 \mathrm{~nm}$ ) prepared from embedded blocks were stained with $\mathrm{KMnO}_{4}$ or incubated with LM19 antibody followed by incubation with secondary antibody labeled with 10-nm colloidal gold particles (BB International, Cardiff, UK). To examine the effect of alkali pretreatment on detection of $\mathrm{HG}$ epitopes, equivalent sections were pre-treated with sodium carbonate for $2 \mathrm{~h}$ at room temperature prior to immunogold labeling (Kim and Daniel 2017). Sections were examined after staining with uranyl acetate. No non-specific binding of secondary antibody (gold particles) was detected in control samples, where the primary antibody was omitted (not shown). Results reflect observations on two different sections.

\section{Results}

\section{Phloem anatomy and lignin distribution}

Phloem anatomy of the tree samples studied is shown in Figs. 1, 2 and Supplemental Fig. 1. There was no notable formation of tension wood in xylem fibers of all tree samples (not shown). All tree samples showed almost the end of cambial growth. Non-collapsed current phloem cells are mainly described in the study with a focus on sieve tube elements (SEs), companion cells (CCs) and (axial/ray) parenchyma cells (double headed arrows in Supplemental Fig. 1). Current phloem rings were determined by an annual tangential ring of axial parenchyma cells (Gričar et al. 2016). Sclereids were detected in collapsed phloem of all tree samples (Supplemental Fig. 1). Phloem fibers were only observed in aspen and oak samples (Supplemental Fig. 1). In all tree samples, positive Mäule (syringyl lignin) and Wiesner (total lignin) reactions for lignin were only detected in sclereids and phloem fibers (Supplemental Fig. 2). The only exception was oak sclereids that showed a negative Mäule reaction. This result indicates differences in lignin composition of sclereids between oak (i.e., guaiacyl lignin) and the three other species (i.e., guaiacyl + syringyl lignin).

\section{Immunofluorescence microscopy in SEs, CCs, and parenchyma cells}

In control samples where the primary antibodies were omitted, no non-specific binding of the secondary antibody (i.e., Alexa 488) was detected (not shown). Immunofluorescence images displayed in the text were captured based on the control images which showed lack of any significant contribution of autofluorescence of phloem cells except for phenolic compounds and cytoplasm of CCs and parenchyma cells (not shown). In many cases, $\mathrm{CC}$ walls were not distinguished directly from neighboring SE- and parenchyma cell walls. In these cases, intensity of epitopes in CC walls was determined based on differences in distribution of epitopes in cell walls between CCs and SEs and between CCs and parenchyma cells. For example, if epitopes were abundant and weak in cell walls between CCs and SEs and between CCs and parenchyma cells, respectively, epitopes in CCs were determined as weak. Overall, no notable differences in distribution of epitopes were detected between axial- and ray parenchyma cells in the study (hereafter termed parenchyma cells). Distributional patterns of pectin and hemicellulose epitopes in SEs, CCs and parenchyma cells are briefly summarized in Table 1.

\section{Detection of side chains of rhamnogalacturonan-I (RG-I) epitopes in SEs, CCs and parenchyma cells}

The presence of RG-I in phloem cells was shown using LM5 and LM6 antibodies that bind to $1,4-\beta$-galactans and 1,5- $\alpha$-arabinans, respectively (Knox 2008; Lee et al. 2013). Although it was not considered in this study, the binding of the LM6 antibody to arabinogalactan proteins (AGPs) was also reported in moss cells (Lee et al. 2005). Figures 1a, d and $2 \mathrm{a}, \mathrm{d}$ are serial sections of immunofluorescence images shown in Figs. 1, 2 and 3.

LM5 epitopes in SEs and CCs (arrowheads) were more abundant in aspen (Fig. 1e) than other three tree species (Figs. 1b, 2b, e). In all tree species, LM5 epitopes were abundantly detected in parenchyma cells, with greater abundance than SEs and CCs (Figs. 1b, e, 2b, e). Unlike the other tree species, ash frequently showed localization of LM5 epitopes in the cytoplasm of parenchyma cells. No LM5 epitopes were detected in sieve plate areas of all tree species (arrows in Figs. 1b, e, 2b, e).

LM6 epitopes were abundantly detected in SEs of all tree species, with greater presence in oak (Fig. 2c) and ash (Fig. 2f) than birch (Fig. 1c) and aspen (Fig. 1f). In CCs, LM6 epitopes were abundant in birch and oak (arrowheads in Figs. 1c, 2c), but were weak in aspen and ash 

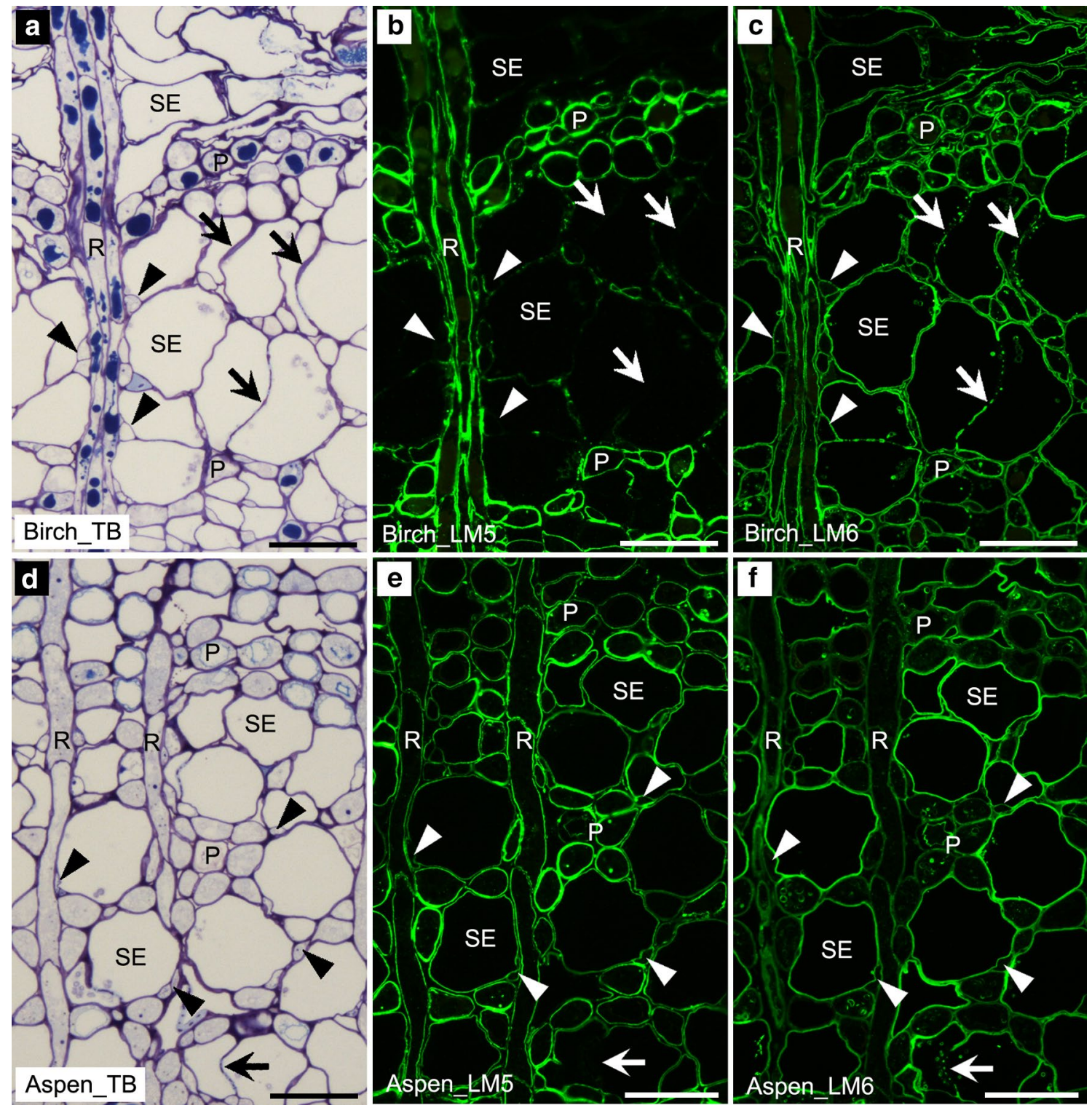

Fig. 1 Detection of LM5 (1,4- $\beta$-galactan) and LM6 (1,5- $\alpha$-arabinan) epitopes in phloem cells of birch and aspen. a-c Serial sections. a Birch phloem stained with toluidine blue (TB) showing sieve tube elements (SEs), companion cells (CCs, arrowheads), (axial/ ray) parenchyma cells (P/R), and sieve plate areas (arrows). b LM5 epitopes in birch phloem showing sparse and abundant localization in SEs/CCs and parenchyma cells, respectively. c LM6 epitopes in birch phloem showing abundant localization in SEs, CCs, and paren- chyma cells. d-f Serial sections. $\mathbf{d}$ Aspen phloem stained with TB. e LM5 epitopes in aspen phloem showing considerable and abundant localization in SEs/CCs and parenchyma cells, respectively. f LM6 epitopes in aspen phloem showing considerable and weak localization in SEs and CCs/parenchyma cells, respectively. Note the absence and presence of LM5 (arrows in b, e) and LM6 (arrows in $\mathbf{c}, \mathbf{f}$ ) epitopes in sieve plate areas of two tree species. Scale bars $50 \mu \mathrm{m}$ (arrowheads in Figs. 1f, 2f). LM6 epitopes in parenchyma cells were overall more abundant in birch (Fig. 1c) than the other species (Figs. 1f, 2c, f), with higher similarity in amounts of epitopes to the other cell types (i.e., SEs and CCs) than the other species. In all tree species, abundant LM6 epitopes were detected in sieve plate areas (arrows in Figs. 1c, f, 2c, f).

\section{Detection of homogalacturonan (HG) epitopes in SEs, CCs, and parenchyma cells}

LM19 (binds to un-/low methyl-esterified HG) epitopes were abundantly detected in all cell types of birch, aspen, and ash phloem (Fig. 3a, b, d). Overall, oak showed much less abundance of LM19 epitopes in all cell types (Fig. 3c) than 

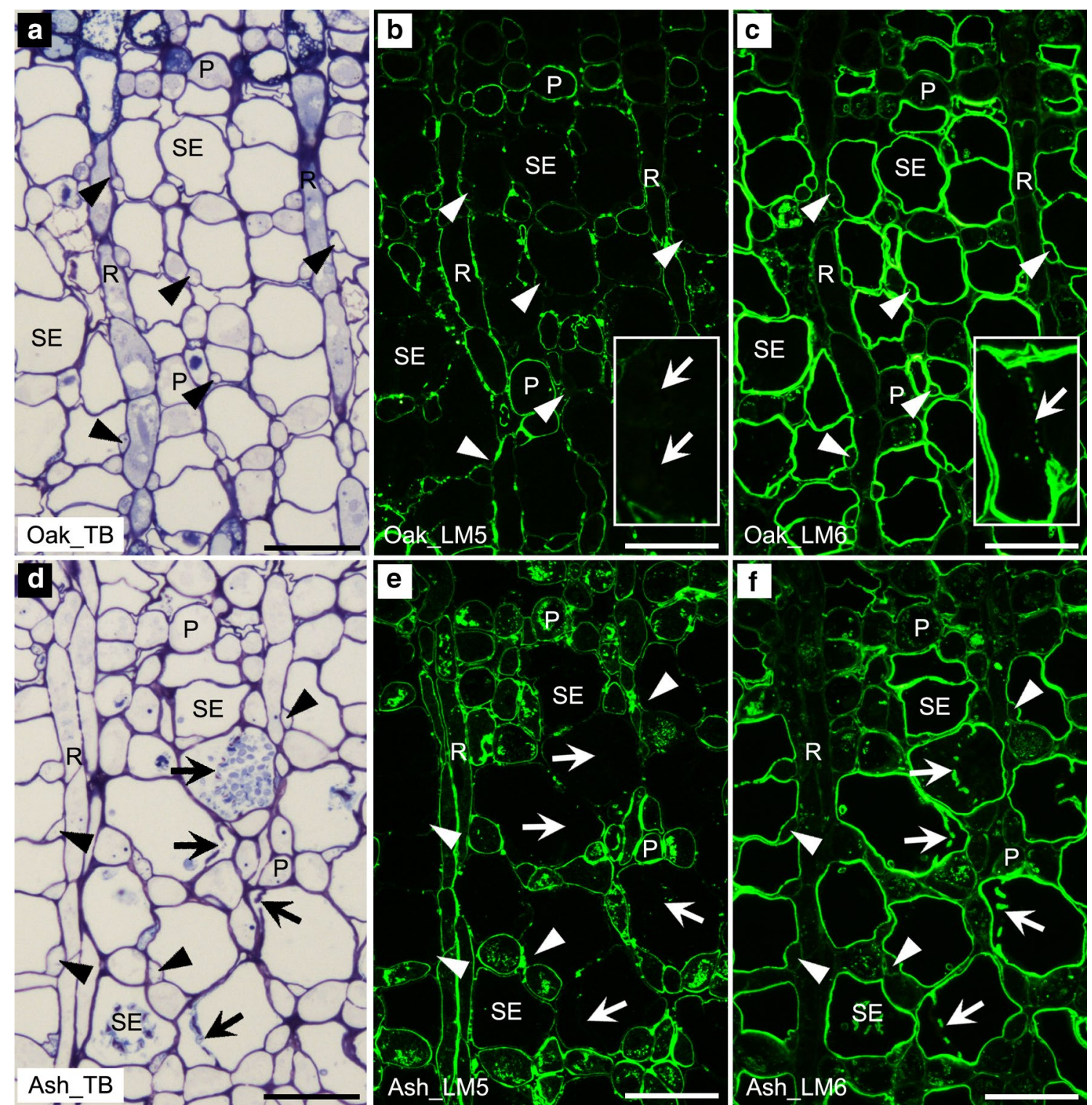

Fig. 2 Detection of LM5 (1,4- $\beta$-galactan) and LM6 (1,5- $\alpha$-arabinan) epitopes in phloem cells of oak and ash. a-c Serial sections. a Oak phloem stained with toluidine blue (TB) showing sieve tube elements (SEs), companion cells (CCs, arrowheads), and (axial/ray) parenchyma cells $(\mathrm{P} / \mathrm{R})$. b LM5 epitopes in oak phloem showing sparse and abundant localization in SEs/CCs and parenchyma cells, respectively. c LM6 epitopes in oak phloem showing abundant and weak localization in SEs/CCs and parenchyma cells, respectively.

the other species (Fig. 3a, b, d). Some notable variations in distribution of LM19 epitopes between cell wall regions/or orientations (i.e., tangential vs. radial) were also observed in SEs and parenchyma cells of oak (Fig. 3c). Sieve plate areas revealed abundant LM19 epitopes in all tree species (arrows in Fig. 3a-d).

Unlike LM19 epitopes, LM20 (binds to highly methylesterified HG) epitopes in SEs and parenchyma cells were overall more abundant in oak (Fig. $3 \mathrm{~g}$ ) than the other d-f Serial sections. d Ash phloem stained with TB. e LM5 epitopes in ash phloem showing sparse and abundant localization in SEs/CCs and parenchyma cells, respectively. f LM6 epitopes in ash phloem showing abundant and weak localization in SEs and CCs/parenchyma cells, respectively. Note the absence and presence of LM5 (arrows in b, e) and LM6 (arrows in $\mathbf{c}, \mathbf{f}$ ) epitopes in sieve plate areas of two tree species. Scale bars $50 \mu \mathrm{m}$

species (Fig. 3e, f, h). Compared to LM19 epitopes, the amount of LM20 epitopes in SEs and parenchyma cells was higher in oak (Fig. 3c vs. g), but was lower in birch (Fig. 3a vs. e), aspen (Fig. 3b vs. f) and ash (Fig. 3d vs. h). In CCs, some weak LM20 epitopes were detected in aspen, oak, and ash, with greater abundance in ash (arrowheads in Fig. 3f-h). Almost no LM20 epitopes were detected in birch CCs (arrowheads in Fig. 3e). In all tree species, 
Table 1 Distribution of pectin and hemicellulose epitopes in the cell wall of sieve tube elements, companion cells and parenchyma cells as reflected by immunofluorescence labeling

\begin{tabular}{|c|c|c|c|c|c|c|c|c|c|}
\hline \multirow[t]{2}{*}{ Phloem cell } & \multirow[t]{2}{*}{ Tree species } & \multicolumn{2}{|l|}{ RG-I } & \multicolumn{2}{|l|}{ HG } & \multirow{2}{*}{$\begin{array}{l}\text { XyG } \\
\text { LM15 }\end{array}$} & \multicolumn{2}{|l|}{ Xylan } & \multirow{2}{*}{$\begin{array}{l}\text { Mannan } \\
\text { LM21 }\end{array}$} \\
\hline & & LM5 & LM6 & LM19 & LM20 & & LM10 & LM11 & \\
\hline \multirow[t]{4}{*}{ Sieve tube element (SE) } & Birch (Di) & $\operatorname{tr}$ & ++ & $+++(+++)$ & $\operatorname{tr} /+(-)$ & $+(+/++)$ & $-/ \operatorname{tr}(-/ \operatorname{tr})$ & - & $-(-)$ \\
\hline & Aspen (Di) & $+/++$ & ++ & $+++(+++)$ & $+/++(-)$ & $+/++(++)$ & $-(-)$ & - & $-(-)$ \\
\hline & Oak (Ri) & $\operatorname{tr} /+$ & +++ & $+(+++)$ & $+++(-)$ & $++(+++)$ & $+/++(+)$ & - & $-(-)$ \\
\hline & Ash (Ri) & $\operatorname{tr} /+$ & +++ & $+++(+++)$ & $+/++(-)$ & $+(+/++)$ & $+/++(+)$ & - & $-(\mathrm{tr} /+)$ \\
\hline \multirow[t]{4}{*}{ Companion cell (CC) } & Birch & $\operatorname{tr}$ & ++ & $+++(+++)$ & $-/ \operatorname{tr}(-)$ & $+(+/++)$ & $-(-)$ & - & $-(-)$ \\
\hline & Aspen & $+/++$ & + & $+++(+++)$ & $\operatorname{tr} /+(-)$ & $+/++(++)$ & $-(-)$ & - & $-(-)$ \\
\hline & Oak & $\operatorname{tr} /+$ & +++ & $+(+++)$ & $+(-)$ & $+(+/++)$ & $-(-)$ & - & $-(-)$ \\
\hline & Ash & $\operatorname{tr}$ & + & $+++(+++)$ & $+/++(-)$ & $\operatorname{tr}(+)$ & $-(-)$ & - & $-(-)$ \\
\hline \multirow[t]{4}{*}{ Parenchyma cell (P/R) } & Birch & +++ & ++ & $+++(+++)$ & $+(-)$ & $++(+++)$ & $-(-)$ & - & $-(-)$ \\
\hline & Aspen & ++ & + & $+++(+++)$ & $++(-)$ & $+/++(++)$ & $-(-)$ & - & $-(-)$ \\
\hline & Oak & ++ & + & $+(+++)$ & $+++(-)$ & $+/++(++)$ & $-(-)$ & - & $-(-)$ \\
\hline & Ash & +++ & + & $+++(+++)$ & $+/++(-)$ & $+/++(++)$ & $-(-)$ & - & $-(-)$ \\
\hline
\end{tabular}

Parentheses indicate intensity of labeling after pre-treatment with sodium carbonate (LM19/20) and sodium carbonate + pectate lyase (LM15/10/21). In brief, number of '+' indicates intensity of labeling. 'tr' trace labeling, '-' no specific labeling

$P / R$ axial/ray parenchyma cell, $D i$ diffuse porous hardwood, $R i$ ring porous hardwood, $R G-I$ rhamnogalacturonan-I, $H G$ homogalacturonan, $X y G$ xyloglucan

LM20 epitopes were detected in sieve plate areas, with greater abundance in oak and ash (arrows in Fig. 3e-h).

\section{Enzymatic removal of homogalacturonan (HG) from phloem cells}

To examine masking effects of pectic HG on detection of hemicellulose epitopes (xyloglucans, heteroxylans, and heteromannans), immunolocalization was carried out using sections pre-treated with pectate lyase (i.e., sodium carbonate + pectate lyase) prior to immunolabeling. Equivalent sections were also pre-treated with only sodium carbonate prior to immunolabeling. In all tree samples, pre-treatment with sodium carbonate resulted in a significant increase in the amount of LM19 HG epitopes in all phloem cells (Fig. 4d) including sclereids and phloem fibers (Figs. 8g, 10f, 12f) compared to controls (Figs. 4c, $8 \mathrm{e}, 10 \mathrm{~d}, 12 \mathrm{~d})$. In contrast, no LM20 epitopes were detected after pre-treatment with sodium carbonate (not shown). After subsequent pre-treatment with pectate lyase, almost no LM19 epitopes were detected in SEs, CCs, and parenchyma cells (Fig. 4b, e) of all tree samples compared to controls (Fig. 4a, c), which indicated removal of most HG from these cells. However, interestingly, some LM19 epitopes were detected in sclereids and phloem fibers even after pre-treatment with pectate lyase (Fig. $4 \mathrm{f}-\mathrm{h}$ ). Thus, the masking effect of $\mathrm{HG}$ on detection of hemicellulose epitopes was only focused on SEs, CCs, and parenchyma cells in the study.

\section{Detection of xyloglucan epitopes in SEs, CCs and parenchyma cells}

LM15 (binds to XXXG motif of xyloglucans) epitopes were detected in all tree species with great variations in distributional patterns between cell types. Birch and ash showed more abundant LM15 epitopes in parenchyma cells than SEs and CCs (arrowheads) (Fig. 5a, c). In contrast, oak revealed more abundant epitopes in SEs than CCs and parenchyma cells (Fig. 5d, e). Aspen showed overall similar LM15 epitopes between cell types (Fig. 5b). In SEs, LM15 epitopes were more readily detected in oak (Fig. 5e) than the other species (Fig. 5a-c). In contrast, LM15 epitopes in parenchyma cells were overall more abundant in birch (Fig. 5a) than the other species (Fig. 5b, c, e). Sieve plate areas revealed considerable amounts of LM15 epitopes in all tree species (arrows in Fig. 5).

After enzymatic removal of HG (i.e., pre-treatment of sections with sodium carbonate + pectate lyase), a notable increase of LM15 epitopes was detected in all tree species without notable changes in distributional patterns of the epitopes (i.e., difference in the amount of epitopes between cell types) (Fig. 5f, Supplemental Fig. 3d-f) compared to controls (Fig. 5e, Supplemental Fig. 3a-c).

\section{Detection of heteroxylan epitopes in SEs, CCs, and parenchyma cells}

LM10 (binds to un-/low substituted heteroxylans) epitopes were not detected in SEs of aspen (not shown) and CCs 

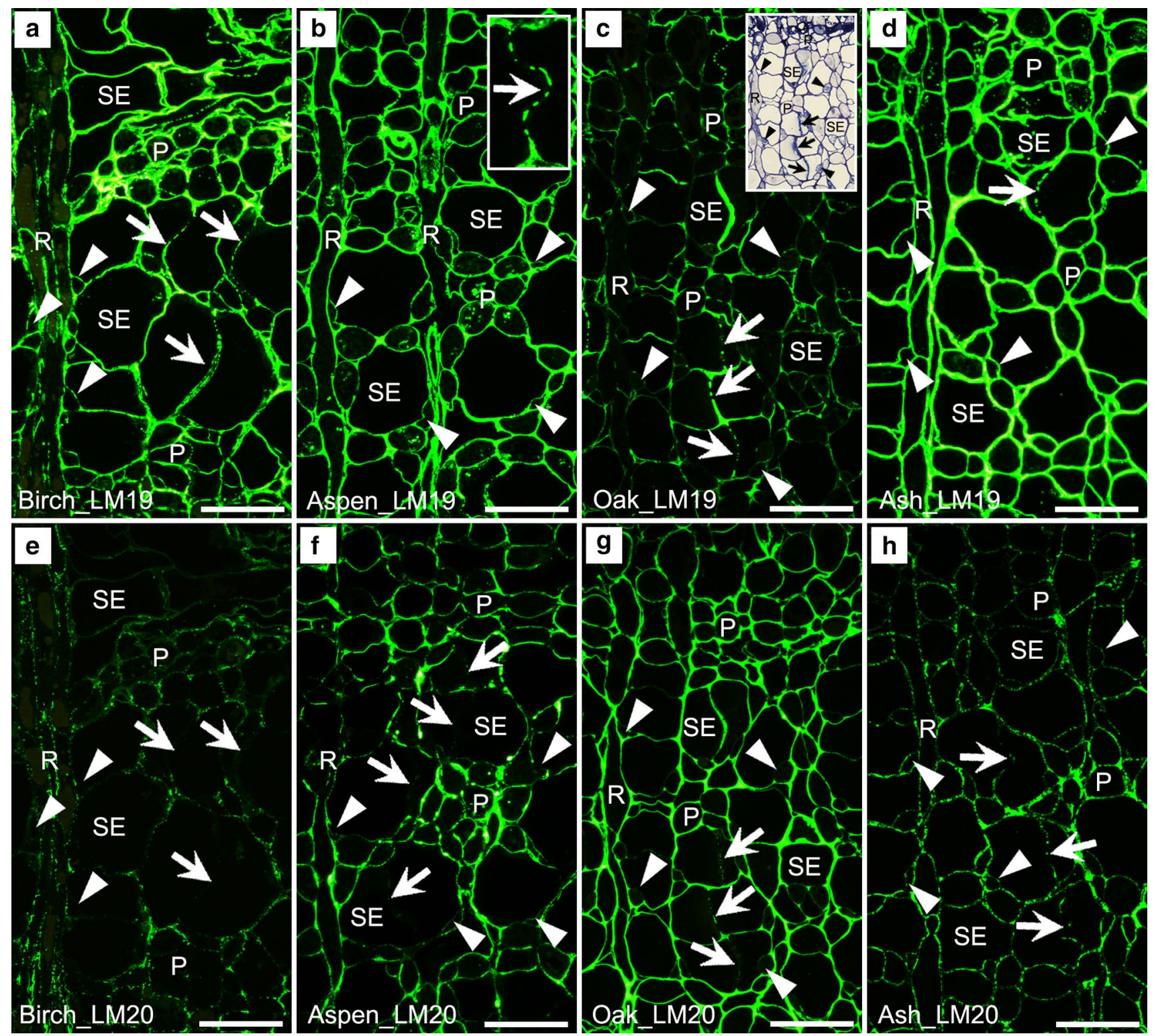

Fig. 3 Detection of LM19 (un-/low methyl-esterified homogalacturonan, HG) and LM20 (highly methyl-esterified HG) epitopes in phloem cells of birch, aspen, oak, and ash. a-d are serial sections of $\mathbf{e}-\mathbf{h} . \mathbf{a}-\mathbf{d}$ LM19 epitopes in phloem cells showing overall greater abundance of epitopes in sieve tube elements (SEs), companion cells (CCs, arrowheads) and (axial/ray) parenchyma cells (P/R) of birch (a), aspen (b), and ash (d) than those of oak (c). e-h LM20 epitopes

(arrowheads) and parenchyma cells of all tree species (Fig. 6). Epitopes were only detected in SEs of birch (Fig. 6b), ash (Fig. 6c), and oak (Fig. 6e) including sieve plate areas, with greater abundance in oak and ash. LM10 epitopes in birch SEs were detected only in a few SEs (Fig. 6a, b). In contrast, all SEs of oak (Fig. 6d, e) and ash (Fig. $6 c$ and inset) showed the presence of epitopes even in phloem cells showing overall greater abundance of epitopes in oak (g) than birch (b), aspen (d), and ash (h) (i.e., opposite to LM19 epitopes). Note opposite patterns of localization between LM19 (c) and LM20 (g) epitopes in oak SEs. Sieve plate areas (arrows) showed abundant and sparse/weak localization of LM19 (a-d) and LM20 (eh) epitopes in all tree species, respectively. Scale bars $50 \mu \mathrm{m}$

though there were some variations in the amount of epitopes between SEs.

After enzymatic removal of $\mathrm{HG}$, no notable changes in distributional patterns of LM10 epitopes were detected in all tree samples (Fig. 6f), with slightly decreased intensity of epitopes in SEs compared to control (Fig. 6e). In all tree samples, no LM11 (binds to highly substituted heteroxylans) epitopes were detected in SEs, CCs, and parenchyma cells (Supplemental Fig. 4a-d). 


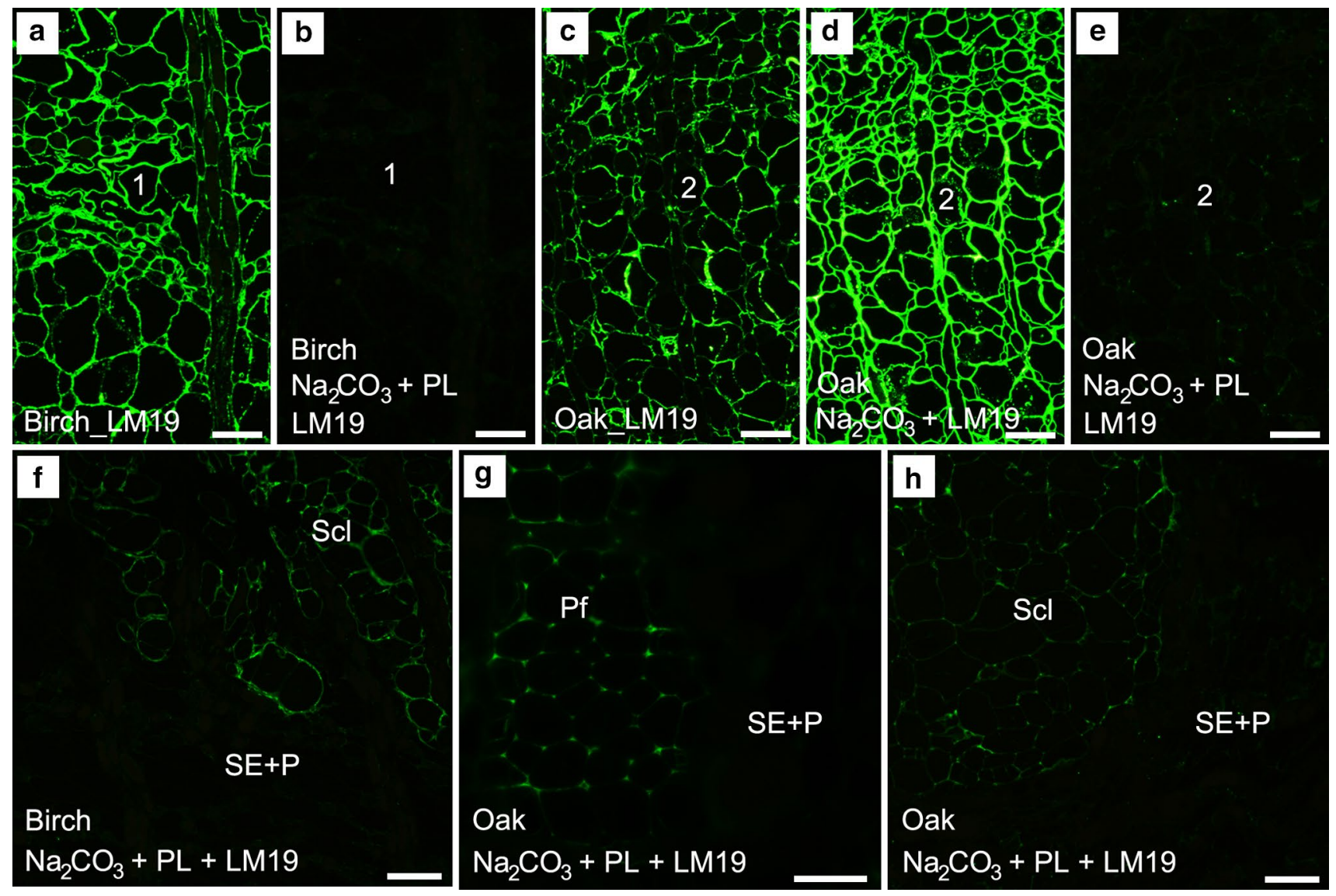

Fig. 4 Detection of LM19 (low methyl-esterified homogalacturonan, $\mathrm{HG}$ ) epitopes in phloem cells of birch and oak after pre-treatment with sodium carbonate $\left(\mathrm{Na}_{2} \mathrm{CO}_{3}\right)$ and pectate lyase (PL). Numbers in $\mathbf{a}-\mathbf{e}$ indicate the same cell. a, b Serial sections of birch phloem showing almost total absence of epitopes in sections pre-treated with $\mathrm{Na}_{2} \mathrm{CO}_{3}+\mathrm{PL}$ (b) compared to control (a). c-e Serial sections of oak phloem showing significant increase and decrease in the amount of

\section{Detection of heteromannan epitopes in SEs, CCs and parenchyma cells}

LM21 epitopes were not detected in any tree samples including SEs, CCs, parenchyma cells, and sieve plate areas, regardless of enzymatic removal of HG (not shown). The only exception was ash SEs that showed some weak labeling for LM21 epitopes after enzymatic removal of HG (Fig. 7).

\section{Anatomical and ultrastructural characteristics of sclereids}

In all tree species, sclereids had thick secondary cell walls and were frequently clumped together (Figs. 8, 10; Supplemental Figs. 1, 4-6). In transverse views, the anatomical structure of sclereids varied greatly in the tree samples. In particular, some sclereids showed much wider cell lumina (Fig. 11a; Supplemental Figs. 1, 5a). With respect to epitopes after pre-treatment with $\mathrm{Na}_{2} \mathrm{CO}_{3}$ (d) and $\mathrm{Na}_{2} \mathrm{CO}_{3}+\mathrm{PL}(\mathbf{e})$, respectively, compared to control $(\mathbf{c})$. $\mathbf{f}-\mathbf{h}$ Birch sclereids $(\mathrm{Scl}, \mathbf{f})$ and oak phloem fibers (Pf, g)/sclereids (h) after pre-treatment with $\mathrm{Na}_{2} \mathrm{CO}_{3}+\mathrm{PL}$. Note the presence and absence of epitopes in sclereids/ phloem fibers and sieve tube elements (SEs)/parenchyma cells (P), respectively. Scale bars $25 \mu \mathrm{m}(\mathbf{a}-\mathbf{e}, \mathbf{g}), 50 \mu \mathrm{m}(\mathbf{f}, \mathbf{h})$

middle lamellae (ML), the thickness and structure of ML varied greatly in birch (Fig. 8a, b) and ash (Supplemental Fig. 6a) sclereids. These variations were much less significant in aspen (Supplemental Fig. 5a) and oak (Fig. 10a). We thus paid special attention to ML of birch and ash sclereids with a focus on variations in thickness using TEM.

Based on staining features of uranyl acetate (i.e., different electron density between cell layers) (Fig. 11), it was shown that ML regions staining strongly with $\mathrm{KMnO}_{4}$ (Fig. 9) were actually composed of ML and primary cell walls (i.e., compound middle lamella, CML). An actual ML-like structure was also detected in sclereids having relatively thick CML after $\mathrm{KMnO}_{4}$ staining (asterisks in Fig. 9d). For comparison in intensity of immunofluorescence labeling between CML, CML of birch and ash sclereids were classified into the two types based on their thickness: (1) thin CML, and (2) thick CML (CML showing distantly thicker than others). 

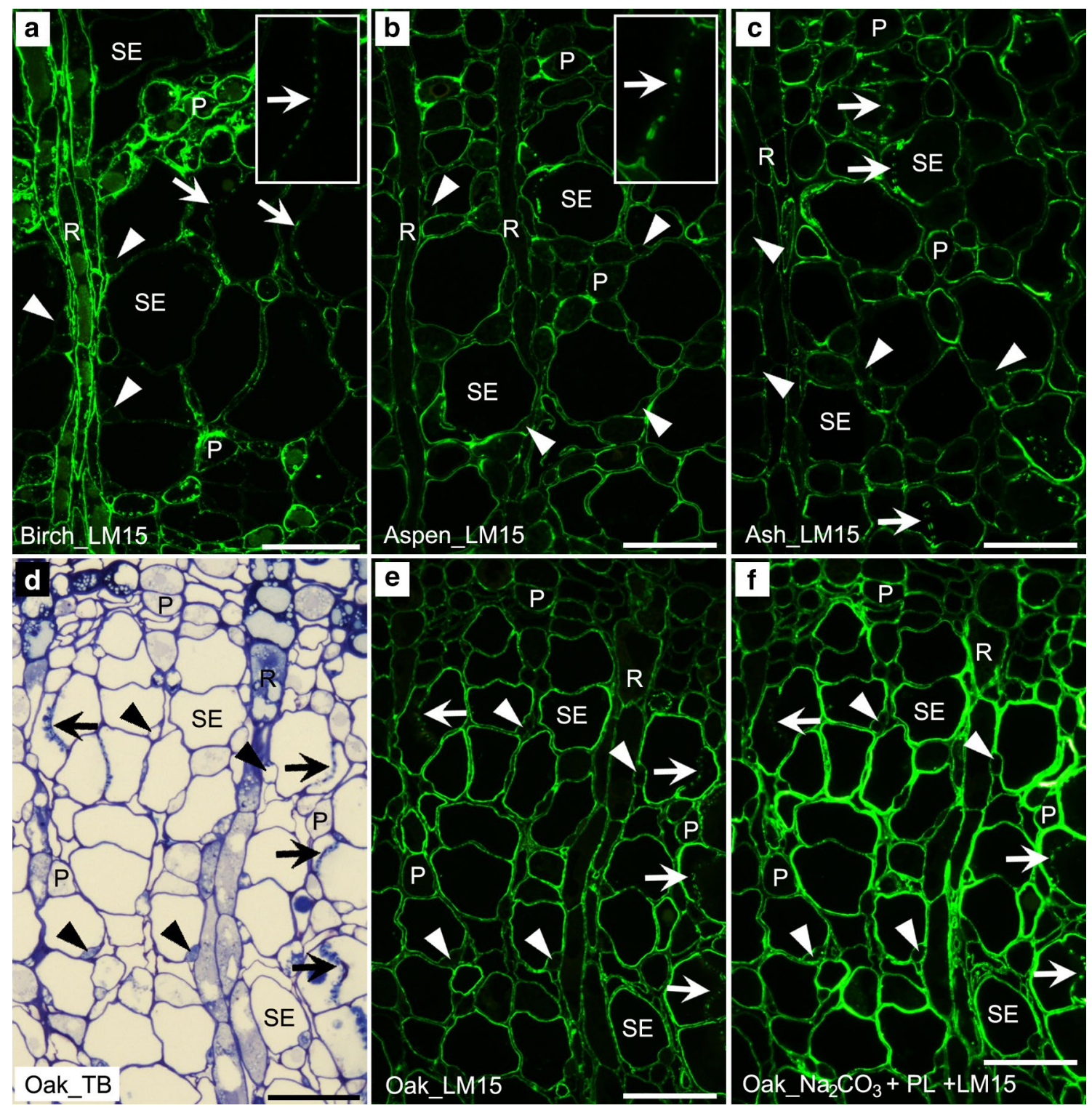

Fig. 5 Detection of LM15 (xyloglucan) epitopes in phloem cells of birch, aspen, oak, and ash. a, $\mathbf{b}$ and $\mathbf{c}$ are serial sections of Figs. 1a, $\mathrm{d}$ and $2 \mathrm{~d}$, respectively. a Birch phloem showing weak and abundant localization of epitopes in sieve tubes (SEs)/companion cells (CCs, arrowheads) and (axial/ray) parenchyma cells (P/R), respectively. b Aspen phloem showing weak localization of epitopes in SEs, CCs, and parenchyma cells. c Ash phloem showing weak localization of epitopes in SEs, CCs, and parenchyma cells. d-f Serial sec-

\section{Detection of pectin epitopes in sclereids}

Distributional patterns of pectin and hemicellulose epitopes in sclereids are briefly summarized in Table 2. LM5 galactan epitopes were sparsely detected in CML of birch (Fig. 8c) and ash (Supplemental Fig. 6b) sclereids, but were abundant in CML of aspen (Supplemental Fig. 5b) and oak (Fig. 10b) sclereids. LM6 arabinan epitopes were abundant in thick CML of birch (arrowheads in Fig. 8d) and ash (arrowheads tions. d Oak phloem stained with toluidine blue (TB) showing sieve tube elements (SEs), companion cells (CCs, arrowheads), and axial/ ray parenchyma cells $(\mathrm{P} / \mathrm{R})$. e Oak phloem showing considerable and weak localization of epitopes in SEs and CCs/parenchyma cells, respectively. f Oak phloem after pre-treatment with sodium carbonate $\left(\mathrm{Na}_{2} \mathrm{CO}_{3}\right)$ and pectate lyase (PL) showing increase in the amount of epitopes compared to control (e). Note localization of epitopes in sieve plate areas (arrows in $\mathbf{a}-\mathbf{f}$ ). Scale bars $50 \mu \mathrm{m}$

in Supplemental Fig. 6c) sclereids, but were sparsely detected in thin CML (arrows in Fig. 8d, Supplemental Fig. 6c). Oak (Fig. 10c) and aspen (Supplemental Fig. 5c) sclereids showed sparse LM6 epitopes in CML.

LM19 HG epitopes were abundant in thick CML of birch (arrowheads in Fig. 8e) and ash (arrowheads in Supplemental Fig. 6d) sclereids, but were sparsely detected in thin CML (arrows in Fig. 8e, Supplemental Fig. 6d). Overall, aspen (Supplemental Fig. 5d) and oak (Fig. 10d) 


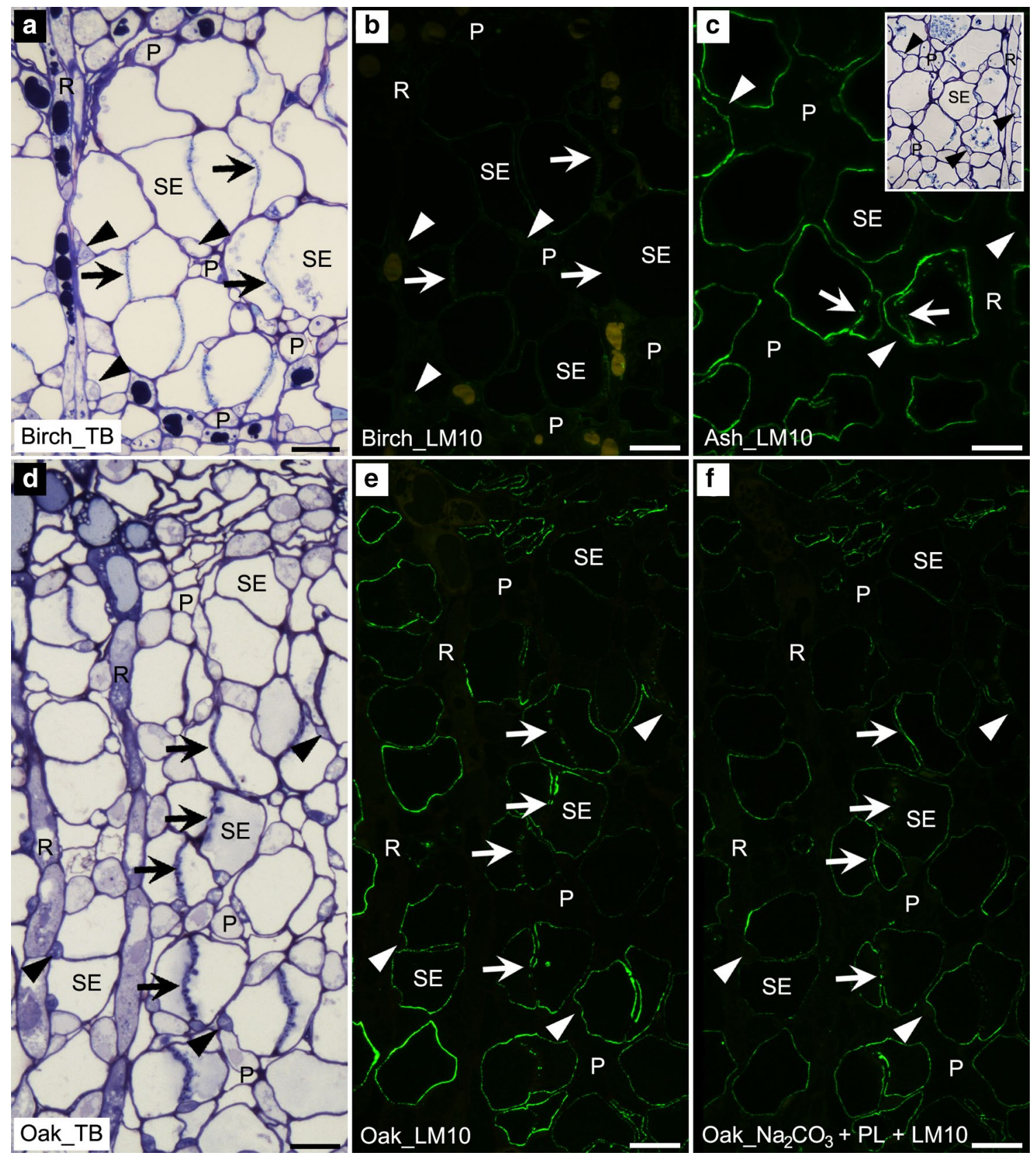

Fig. 6 Detection of LM10 (heteroxylan) epitopes in phloem cells of birch, ash, and oak. a, b Serial sections of birch phloem showing sparse epitopes in sieve tube elements (SEs) including sieve plate area (arrows) and absence of epitopes in companion cells (CCs, arrowheads) and (axial/ray) parenchyma cells (P/R). c Ash phloem showing distribution of epitopes in SEs including sieve plate area. The inset stained with toluidine blue (TB) indicates the same anatom-

sclereids showed sparse LM19 epitopes in CML. LM20 HG epitopes were abundantly detected in thick CML of birch (arrowheads in Fig. 8f) and ash (arrowheads in Supplemental Fig. 6e) sclereids, but were sparsely detected in thin CML of birch and ash (arrows in Fig. 8f, Supplemental Fig. 6e) and CML of oak and aspen (Fig. 10e, ical region to the immunofluorescence image. $\mathbf{d}-\mathbf{f}$ Serial sections of oak phloem showing presence and absence of epitopes in SEs including sieve plate area and CCs/parenchyma cells, respectively. Note no notable changes in distributional patterns of epitopes and slightly decreased localization of epitopes after pre-treatment with sodium carbonate $\left(\mathrm{Na}_{2} \mathrm{CO}_{3}\right)$ and pectate lyase (PL) (f) compared to control (e). Scale bars $25 \mu \mathrm{m}$

Supplemental Fig. 5e). After pre-treatment with sodium carbonate prior to immunolocalization, LM19 epitopes in CML of sclereids increased significantly in all tree samples, particularly in thin CML (arrows in Figs. 8g, 10f; Supplemental Figs. 5f, 6f) compared to sections before pre-treatment (arrows in Figs. 8e, 10d; Supplemental 

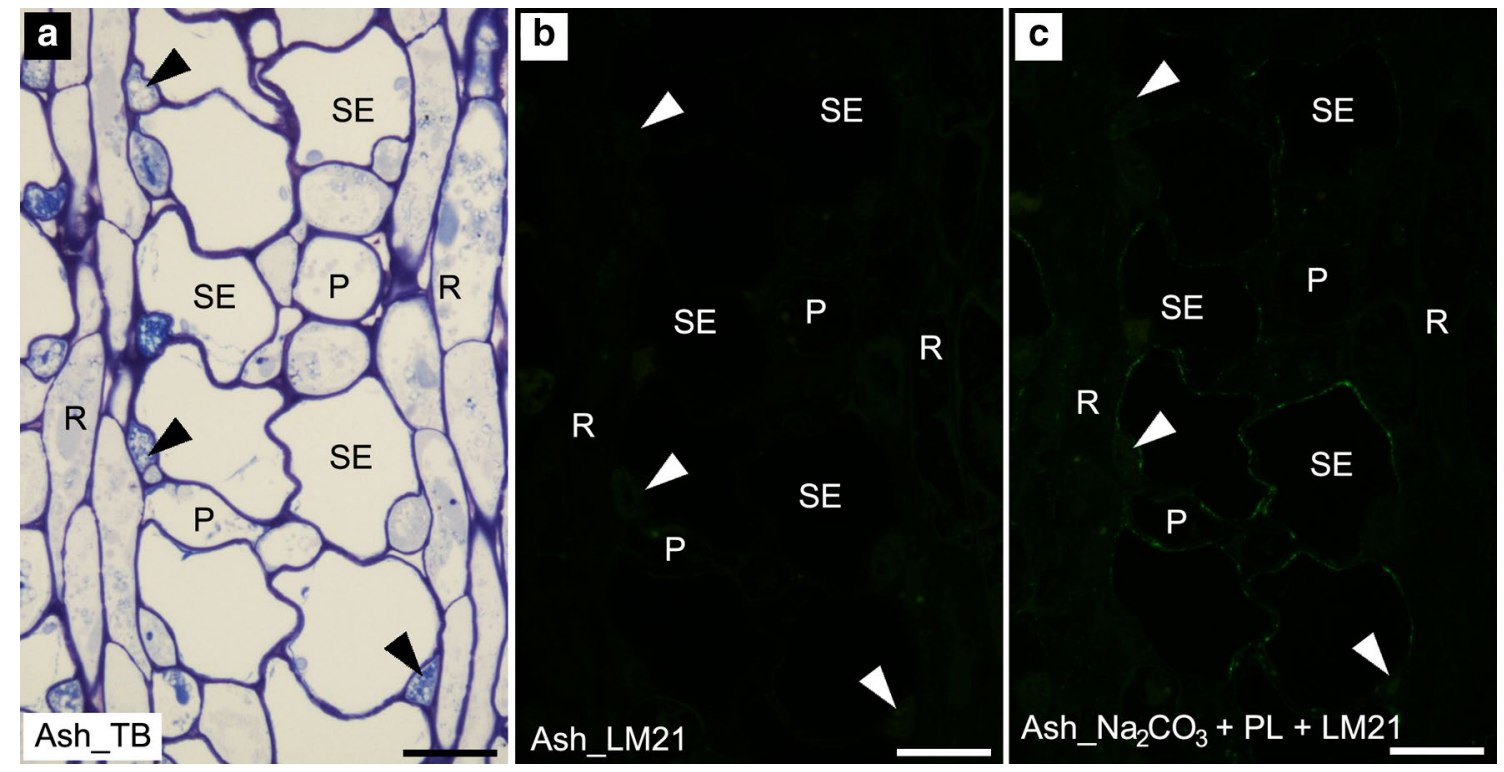

Fig. 7 Detection of LM21 (heteromannan) epitopes in phloem cells of ash. a-c Serial sections. a Staining with toluidine blue (TB) showing sieve tube elements (SEs), companion cells (CCs, arrowheads), (axial/ray) parenchyma cells (P/R). b, c Detection of epitopes before

Figs. 5d, 6d). In contrast, LM20 epitopes were not detected after pre-treatment (not shown).

Information on differences in distribution of LM19 epitopes between CML was further advanced in birch sclereids by TEM immunogold labeling. Like immunofluorescence observations, thin CML showed very sparse gold labeling (Fig. 11a, b), whereas thick CML revealed abundant gold particles (Fig. 11b-d). Variations in the number of gold particles were also observed within the same thick CML (Fig. 11b-d). After pre-treatment with sodium carbonate prior to immunogold labeling, LM19 epitopes were abundantly detected in thin CML in agreement with immunofluorescence labeling. Thick CML also showed a more even distribution of LM19 epitopes across CML (Fig. 11f, g) than before pre-treatment (Fig. 11b-d).

\section{Detection of hemicellulose epitopes in sclereids}

LM15 xyloglucan epitopes were detected in CML of sclereids in all tree samples (Figs. $8 \mathrm{~h}, 10 \mathrm{~g}$; Supplemental Figs. $5 \mathrm{~g}, 6 \mathrm{~g}$ ) and were particularly abundant in thick CML of birch (arrowheads in Fig. 8h) and ash (arrowheads in Supplemental Fig. 6g) sclereids. No LM15 epitopes were detected in secondary cell walls of sclereids (Figs. 8h, 10g; Supplemental Figs. 5g, 6g).

LM10/11 heteroxylan epitopes were abundantly detected in secondary cell walls of sclereids in all tree samples (Figs. 8i, 10h; Supplemental Figs. 4e-h, 5h, 6h) but were not and after pre-treatment with sodium carbonate $\left(\mathrm{Na}_{2} \mathrm{CO}_{3}\right)$ and pectate lyase (PL), respectively. Note the presence of some weak epitopes in SEs after pre-treatment with $\mathrm{Na}_{2} \mathrm{CO}_{3}+\mathrm{PL}$ (c). Scale bars $25 \mu \mathrm{m}$

detected in CML of sclereids (Figs. 8i, 10h; Supplemental Figs. 4e-h, 5h, 6h).

LM21 heteromannan epitopes were not detected in secondary cell walls of sclereids in any tree samples. In contrast, some LM21 epitopes were detected in CML of birch and ash sclereids, particularly in thicker CML (arrowheads in Fig. 8j and Supplemental Fig. 6i). Some weak LM21 epitopes were also detected in aspen, specifically in thick CML-like structures formed between sclereids and neighboring cells (arrowheads in Supplemental Fig. 5a, i) and CML of sclereids having significant difference in anatomical structure from other sclereids (asterisk in Supplemental Fig. 5a, i). LM 21 epitopes were not detected in CML of oak sclereids (Fig. 10i).

\section{Anatomical characteristics of phloem fibers}

Phloem fibers were only observed in aspen and oak samples (Supplemental Fig. 1). After staining with toluidine blue, the inner layer of fiber cell walls showed different staining features from the outer layer (inset in Fig. 12a and Supplemental Fig. 7a), indicating heterogeneity in cell wall chemistry between inner- and outer layers. In particular, the inner layer of oak phloem fibers showed purple color, which was particularly prominent in the innermost layers (Supplemental Fig. 7a and inset). This staining feature is similar to gelatinous $(\mathrm{G})$ fibers (i.e., no or low lignified cell wall) in tension wood (Kim and Daniel 2012a). Fluorescence microscopy also showed much less intensity of autofluorescence 

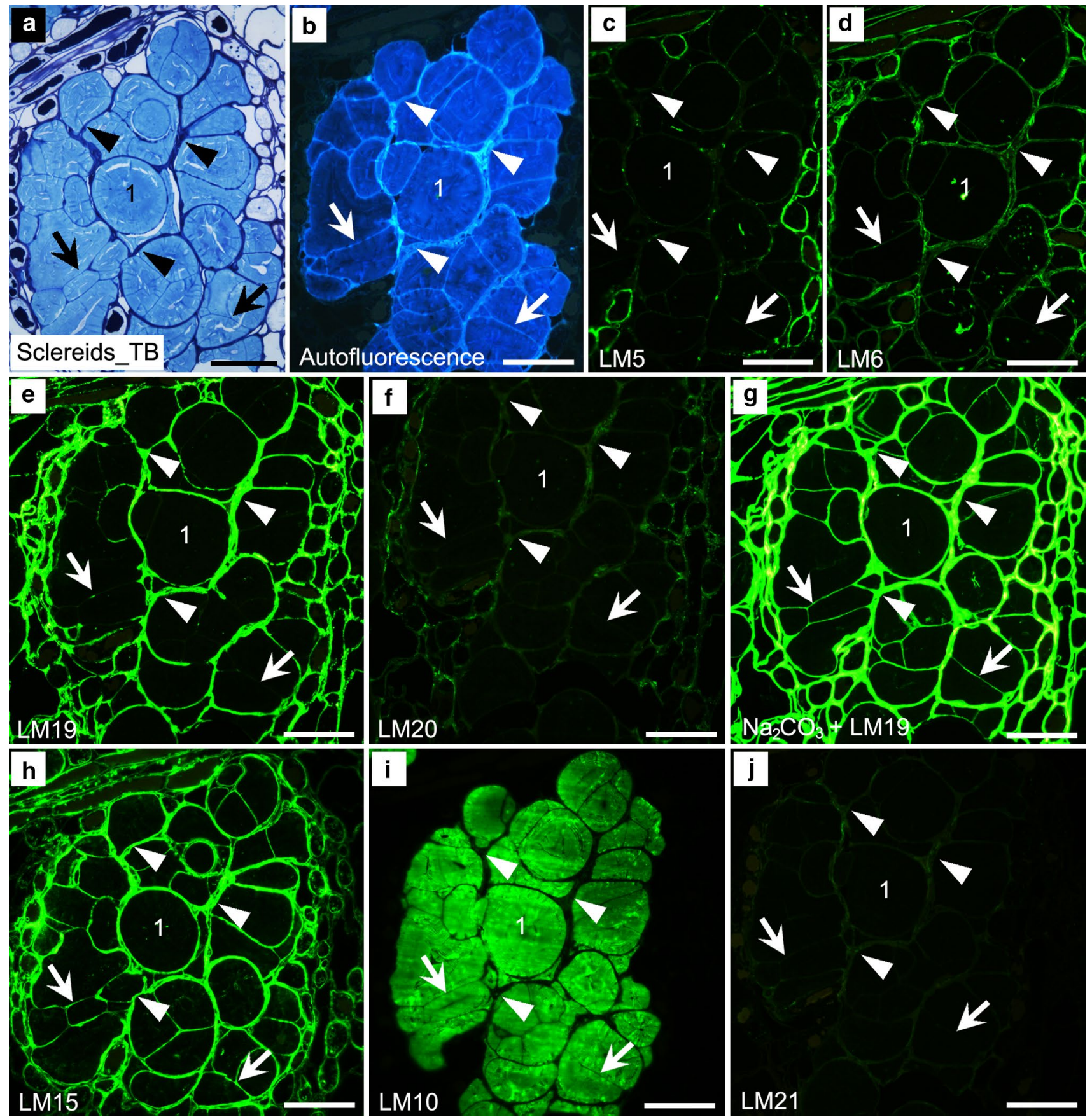

Fig. 8 Detection of pectin and hemicellulose epitopes in birch sclereids. a-j Serial sections. Numbers indicate the same cell. a Staining with toluidine blue (TB) showing variations in thickness of compound middle lamellae (CML) between sclereids; thin (arrow)- and thick (arrowheads) CML. b Autofluorescence of sclereids under UV excitation (340-380 $\mathrm{nm}$ ). Note stronger intensity in CML than secondary cell wall, no matter thin or thick CML. c Detection of LM5 (galactan) epitopes showing sparse localization in CML. d Detection of LM6 (arabinan) epitopes showing sparse and weak localization in thin- and thick CML, respectively. e Detection of LM19 (un-/ low methyl-esterified HG) epitopes showing sparse and abundant localization in thin- and thick CML, respectively. $\mathbf{f}$ Detection of
LM20 (highly methyl-esterified HG) epitopes showing sparse and weak localization in thin- and thick CML, respectively. g Detection of LM19 epitopes on sections pre-treated with sodium carbonate $\left(\mathrm{Na}_{2} \mathrm{CO}_{3}\right)$ showing significantly increased localization in CML compared to control (e). h Detection of LM15 (xyloglucan) epitopes showing abundant localization in CML, with greater abundance in thick- than thin CML. i Detection of LM10 (heteroxylan) epitopes showing abundant localization in secondary cell walls. Note absence of epitopes in CML. j Detection of LM21 (heteromannan) epitopes showing weak localization in thick CML and sparse in thin CML. Scale bars $50 \mu \mathrm{m}$ 

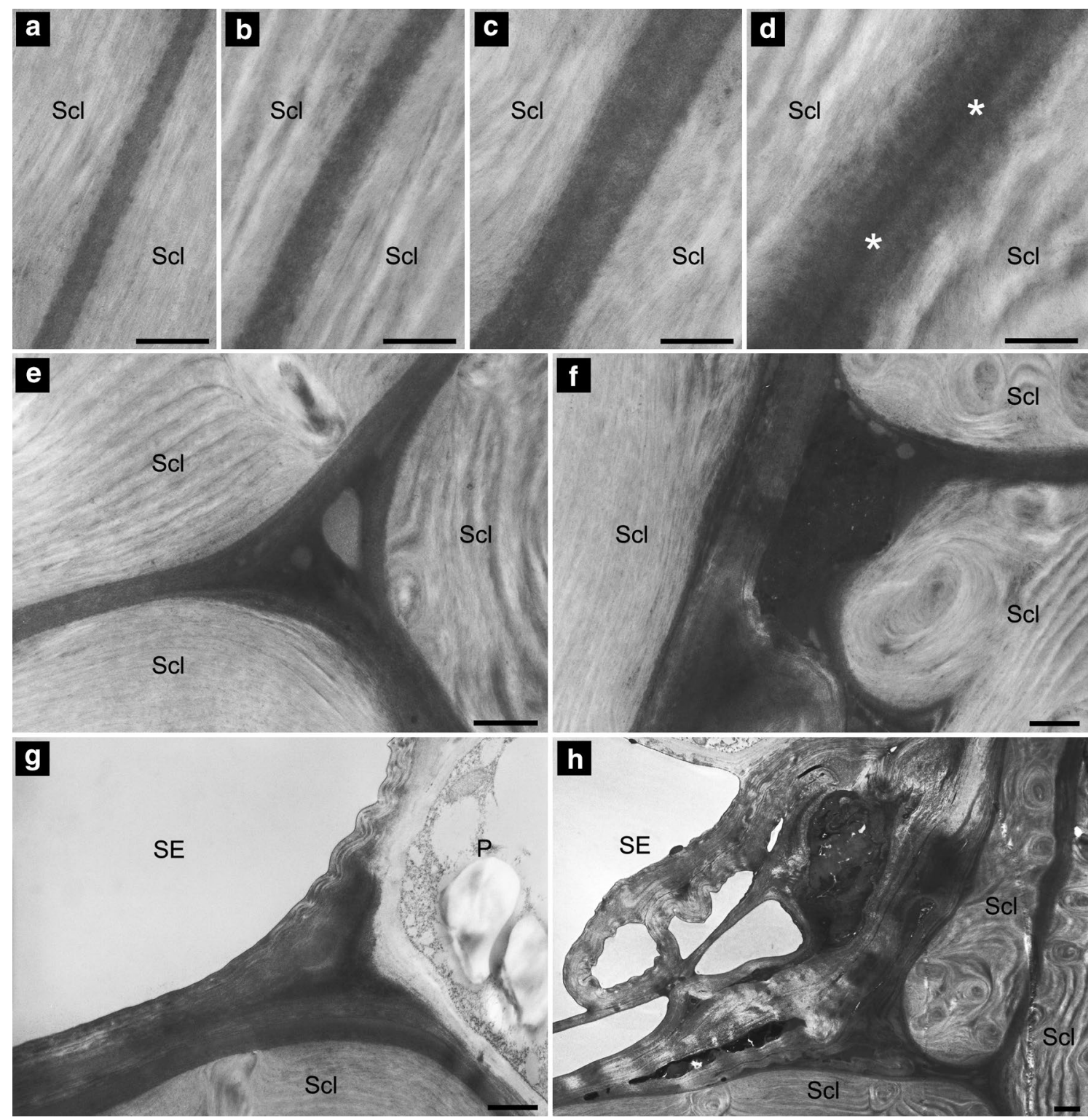

Fig. 9 Ultrastructure of compound middle lamellae (CML) in birch sclereids after staining with $\mathrm{KMnO}_{4}$. Note great variations in the thickness and structure of CML between sclereids ( $\mathrm{Scl})$. Asterisks

in $\mathbf{d}$ indicate the actual middle lamella. $\mathrm{P}$, axial parenchyma cell; SE, sieve tube element. Scale bars $500 \mathrm{~nm}(\mathbf{a}-\mathbf{d}), 1 \mu \mathrm{m}(\mathbf{e}-\mathbf{h})$

under UV excitation in the inner- than outer layers of fibers (Supplemental Fig. 7d, i). However, this inner layer showed a positive Wiesner and Mäule reactions for lignin (Supplemental Fig. 2) and abundant distribution of heteroxylan epitopes (Supplemental Figs. 4, 7), which differ from the general features of gelatinous layers. Nanko and Côté (1980) reported that phloem fibers of white oak and southern red oak have an $\mathrm{S} 1+\mathrm{S} 2+\mathrm{G}$ (gelatinous layer) structure and $\mathrm{G}$ layer of these oak species is weakly lignified. The inner layer of aspen phloem fibers also showed similar characteristics of autofluorescence, lignin staining, and distribution of heteroxylan epitopes (see below) to oak phloem fibers, even though development of purple color was less clear than in oak. In the study, we only focused on distribution of epitopes, no matter the cell wall structure of phloem fiber (i.e., whether or not $\mathrm{G}$ layer is present). Outer cells associated with fiber bundles frequently showed abnormal cell wall structure (asterisks in Fig. 12a and Supplemental Fig. 7a).

\section{Detection of pectin epitopes in phloem fibers}

The distributional patterns of pectin and hemicellulose epitopes in phloem fibers are briefly summarized in Table 2 . 
Table 2 Distribution of pectin and hemicellulose epitopes in phloem sclereids and fibers as reflected by immunofluorescence labeling

\begin{tabular}{|c|c|c|c|c|c|c|c|c|c|}
\hline \multirow[t]{2}{*}{ Phloem cell } & \multirow[t]{2}{*}{ Tree species } & \multicolumn{2}{|l|}{ RG-I } & \multicolumn{2}{|l|}{ HG } & \multirow{2}{*}{$\begin{array}{l}\text { XyG } \\
\text { LM15 }\end{array}$} & \multicolumn{2}{|l|}{ Xylan } & \multirow{2}{*}{$\begin{array}{l}\text { Mannan } \\
\text { LM21 }\end{array}$} \\
\hline & & LM5 & LM6 & LM19 & LM20 & & LM10 & LM11 & \\
\hline \multirow[t]{14}{*}{ Sclereid } & SW & & & & & & & & \\
\hline & Birch (Di) & - & - & - & - & - & +++ & +++ & - \\
\hline & Aspen (Di) & - & - & - & - & - & +++ & +++ & - \\
\hline & Oak (Ri) & - & - & - & - & - & +++ & +++ & - \\
\hline & Ash (Ri) & - & - & - & - & - & +++ & +++ & - \\
\hline & CML & & & & & & & & \\
\hline & Birch & & & & & & & & \\
\hline & Thin & $\operatorname{tr}$ & $\operatorname{tr}$ & $\operatorname{tr}(+++)$ & $\operatorname{tr}(-)$ & +++ & - & - & $-/ \operatorname{tr}$ \\
\hline & $\begin{array}{l}\text { Thick } \\
\text { Aspen }\end{array}$ & $\operatorname{tr}$ & $+/++$ & $+++(+++)$ & $+/++(-)$ & +++ & - & - & + \\
\hline & $\begin{array}{l}\text { Thin } \\
\text { Oak }\end{array}$ & ++ & $\operatorname{tr}$ & $\operatorname{tr}(++)$ & $\operatorname{tr}(-)$ & $+/++$ & - & - & $\operatorname{tr} /+$ \\
\hline & Thin & ++ & $\operatorname{tr}$ & $\operatorname{tr}(++)$ & $\operatorname{tr}(-)$ & $+/++$ & - & - & - \\
\hline & Ash & & & & & & & & \\
\hline & Thin & $-/ \operatorname{tr}$ & $-/ \operatorname{tr}$ & $\operatorname{tr}(+++)$ & $\operatorname{tr}(-)$ & $+/++$ & - & - & $\operatorname{tr} /+$ \\
\hline & Thick & $\operatorname{tr}$ & $+/++$ & $+++(+++)$ & $+/++(-)$ & ++ & - & - & $+/++$ \\
\hline \multirow[t]{5}{*}{ Fiber } & SW & & & & & & & & \\
\hline & Aspen & - & - & - & - & $-/ \operatorname{tr}$ & +++ & +++ & - \\
\hline & $\begin{array}{c}\text { Oak } \\
\text { CML }\end{array}$ & - & - & - & - & $\operatorname{tr}$ & +++ & +++ & - \\
\hline & Aspen & ++ & $-/ \operatorname{tr}$ & $\operatorname{tr}(+++)$ & $\operatorname{tr} /+(-)$ & ++ & $-/ \operatorname{tr}$ & $-/ \operatorname{tr}$ & - \\
\hline & Oak & +++ & $\operatorname{tr} /+$ & $\operatorname{tr}(+++)$ & $\operatorname{tr} /+(-)$ & ++ & $-/ \operatorname{tr}$ & $-/ \operatorname{tr}$ & - \\
\hline
\end{tabular}

Parentheses indicate intensity of labeling after pre-treatment with sodium carbonate. In brief, number of ' + ' indicates intensity of labeling. 'tr' trace labeling, ' - ' no specific labeling

$S W$ secondary cell wall, $C M L$ compound middle lamella, $D i$ diffuse porous hardwood; $R i$ ring porous hardwood, $R G-I$ rhamnogalacturonan-I, $H G$ homogalacturonan, $X y G$ xyloglucan
Both aspen and oak fibers showed similar distributional patterns of pectin and hemicellulose epitopes.

LM5 galactan epitopes were abundant in CML of fibers (Fig. 12b, Supplemental Fig. 7b), whereas LM6 arabinan epitopes were sparsely/or weakly detected (Fig. 12c, Supplemental Fig. 7c). LM19/20 HG epitopes were sparsely/or weakly detected in CML of fibers (Fig. 12d, e; Supplemental Fig. 7d, e). However, after pre-treatment with sodium carbonate, LM19 epitopes increased significantly in CML (Fig. 12f, Supplemental Fig. 7f) compared to before pretreatment (Fig. 12d, Supplemental Fig. 7d).

\section{Detection of hemicellulose epitopes in phloem fibers}

LM15 xyloglucan epitopes were prominent in CML of fibers (Fig. 12g, Supplemental Fig. 7g). Sparse LM15 epitopes were also detected in secondary cell walls of some phloem fibers, particularly in aspen (inset in Fig. 12g). LM10/11 heteroxylan epitopes were abundant in secondary cell walls of fibers, with greater abundance in outer- than inner cell walls (Fig. 12h, Supplemental Figs. 4i, j, 7h). Some LM10/11 epitopes were also detected in CML of a few phloem fibers, particularly middle lamella cell corner (Fig. 12h, Supplemental Figs. 4i, j, 7h). Specific LM21 heteromannan epitopes were not detected in phloem fibers (not shown).

\section{Discussion}

To extend our understanding of hardwood phloem chemistry at the individual cell level, this study carried out immunolocalization of pectin and hemicellulose epitopes combined with eight monoclonal antibodies on four hardwood species. For correct interpretation of results, it is important to note that this study is mainly focused on understanding of differences in distributional patterns of epitopes between cell types and between tree species when applying the same antibody. In the study, the absence of epitopes does not directly indicate the complete absence of a component, since the antibodies used cannot cover all chemical structures of a single pectin or hemicellulose component. Additional studies using further glycan-directed probes will provide more detailed in situ information on 

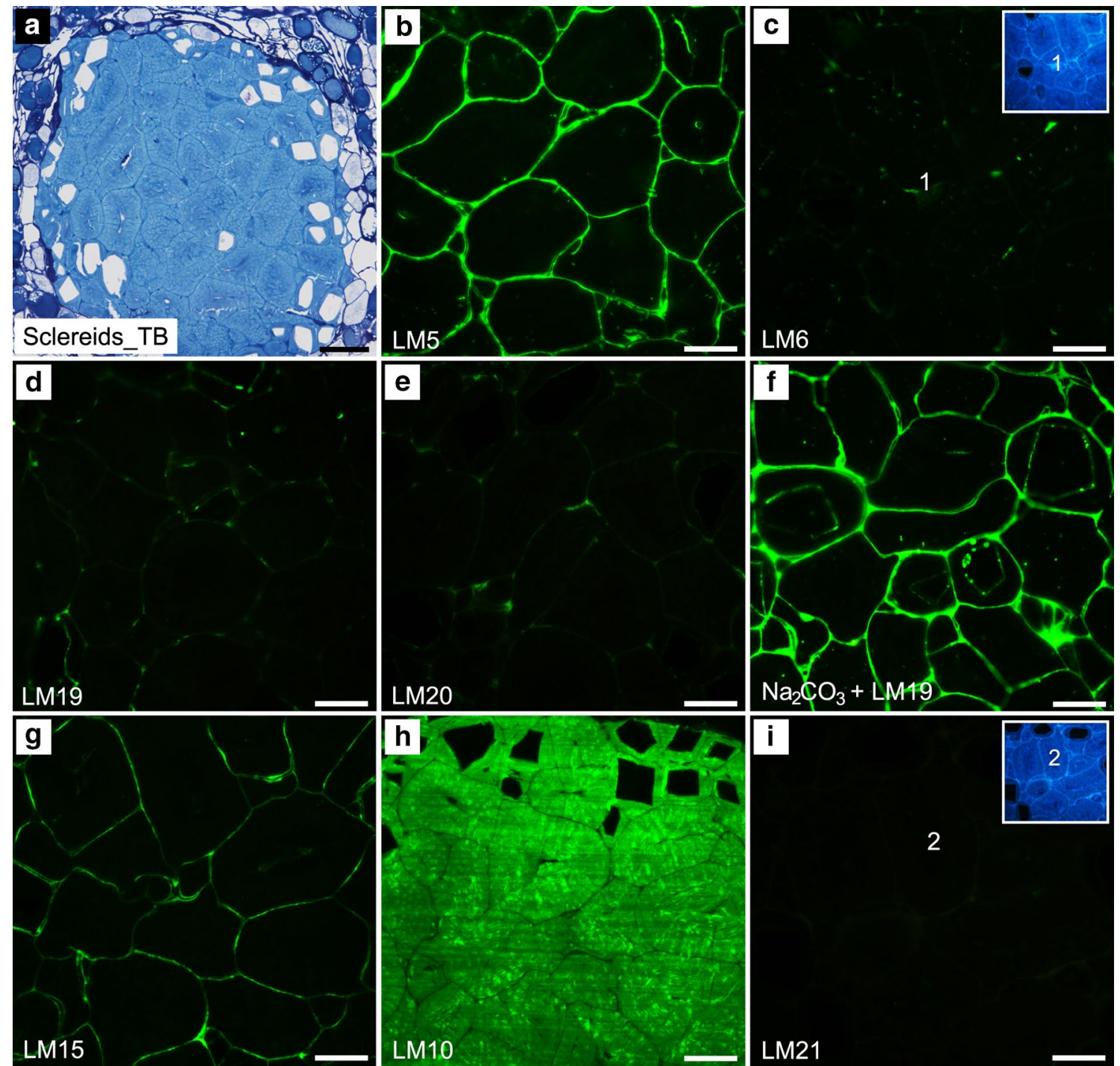

Fig. 10 Detection of pectin and hemicellulose epitopes in oak sclereids. a-i Serial sections. Insets in $\mathbf{c}$ and $\mathbf{i}$ show autofluorescence of sclereids under UV excitation (340-380 nm). Numbers indicate the same cell. a Staining with toluidine blue (TB) showing overall homogeneity in thickness of compound middle lamellae (CML) between sclereids. b, c Detection of LM5 (galactan) and LM6 (arabinan) epitopes showing abundant and sparse localization in CML. d, e Detection of LM19 (un-/low methyl-esterified HG) and LM20 (highly methyl-esterified HG) epitopes showing sparse localization in
CML. f Detection of LM19 epitopes on the section pre-treated with sodium carbonate $\left(\mathrm{Na}_{2} \mathrm{CO}_{3}\right)$ showing significantly increased localization in CML compared to control (d). g Detection of LM15 (xyloglucan) epitopes showing considerable localization in CML. h Detection of LM10 (heteroxylan) epitopes showing abundant localization in secondary cell walls. i Detection of LM21 (heteromannan) epitopes showing absence of localization in sclereids. Scale bars $50 \mu \mathrm{m}(\mathbf{a})$, $25 \mu \mathrm{m}(\mathbf{b}-\mathbf{i})$

this study should be interpreted on various possibilities of masking that were not examined. Moreover, although no notable difference was detected in distributional patterns of epitopes between collapsed (not displayed in this study)- and non-collapsed phloem, we cannot completely exclude the possibility for changes in distribution patterns of epitopes during the maturation process of phloem cells (i.e., during collapsing process of phloem), particularly living parenchyma cells. 


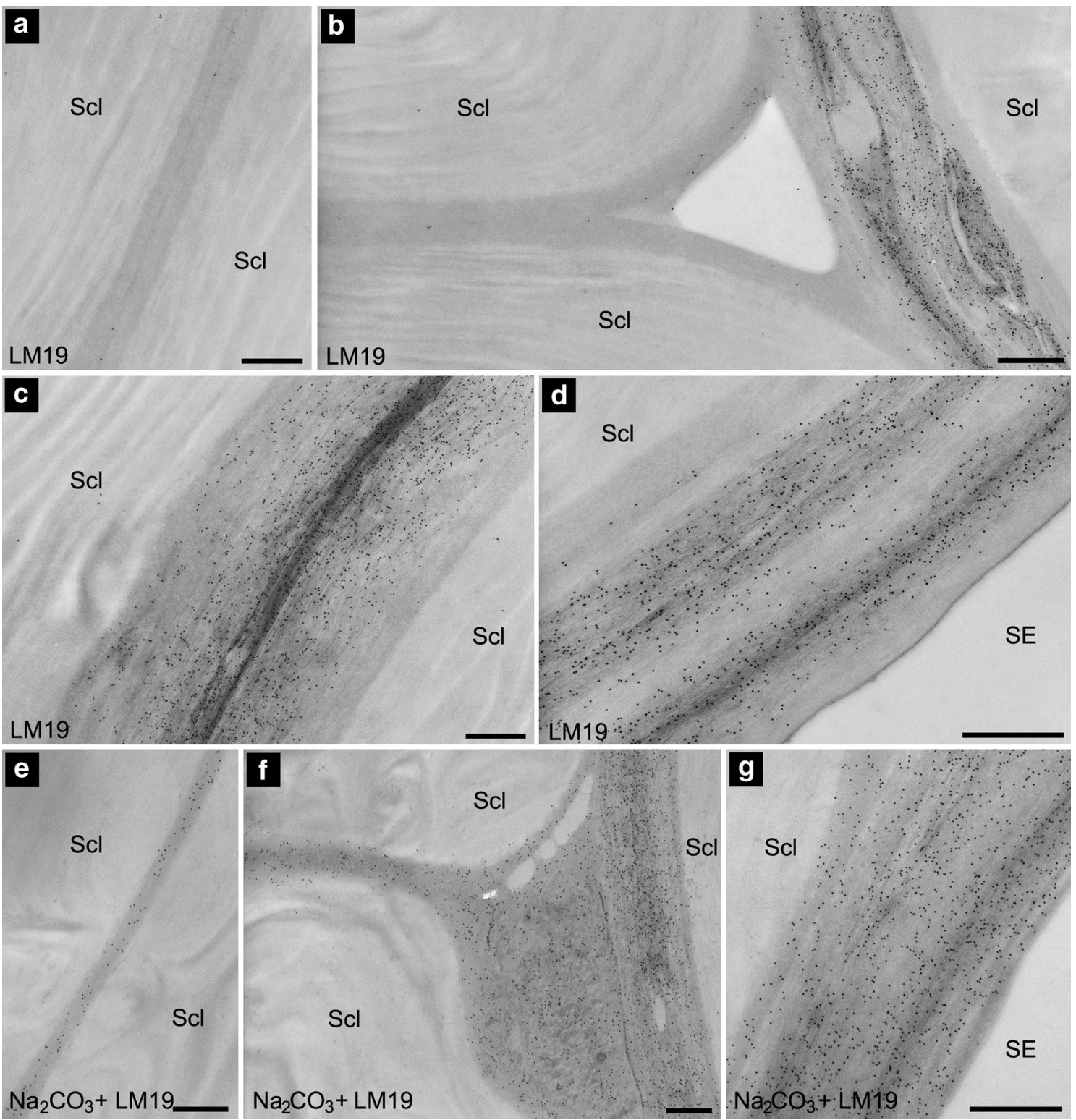

Fig. 11 Immunogold labeling of LM19 (un-/low methyl-esterified $\mathrm{HG})$ epitopes in birch sclereids $(\mathrm{Scl})$. Staining with uranyl acetate. a-d Sections without pre-treatment with sodium carbonate $\left(\mathrm{Na}_{2} \mathrm{CO}_{3}\right)$ showing sparse and abundant gold particles in thin- and thick compound middle lamellae (CML), respectively $(\mathbf{a}, \mathbf{b})$. Note variations in the amount of gold particles across thick CML (b-d). e-g Sections pre-treated with $\mathrm{Na}_{2} \mathrm{CO}_{3}$ showing increased localization of gold particle in thin CML $(\mathbf{e}, \mathbf{f})$. Note increased homogeneity in distribution of gold particles across the thick CML (f, g). Scale bars $500 \mathrm{~nm}$

\section{The effect of pre-treatments on detection of pectin and hemicellulose epitopes in hardwood phloem}

Several recent studies using immunolocalization approaches have shown that the enzymatic removal of pectic homogalacturonan (HG) from plant sections can increase the detection of hemicellulose epitopes in several annual plant cell walls (Hernandez-Gomez et al. 2015; Hervé et al. 2009; Kim and Daniel 2012b, c; Marcus et al. 2008, 2010). Our recent study on softwood phloem also showed the masking effect of HG on detection of hemicellulose epitopes (Kim and Daniel 2017). This study also demonstrates that HG in hardwood phloem cells can mask access to LM15 xyloglucan and LM21 heteromannan epitopes. The enzymatic removal of $\mathrm{HG}$ from phloem sections increased detection of LM15 epitopes in SEs, CCs and parenchyma cells (Fig. 5e, f; Supplemental Fig. 3). The masking effect of HG on detection of LM21 epitopes was also detected in ash SEs (Fig. 7). However, at present, it is unclear whether the absence of LM21 epitopes in pre-treated SEs of birch, aspen, and oak 


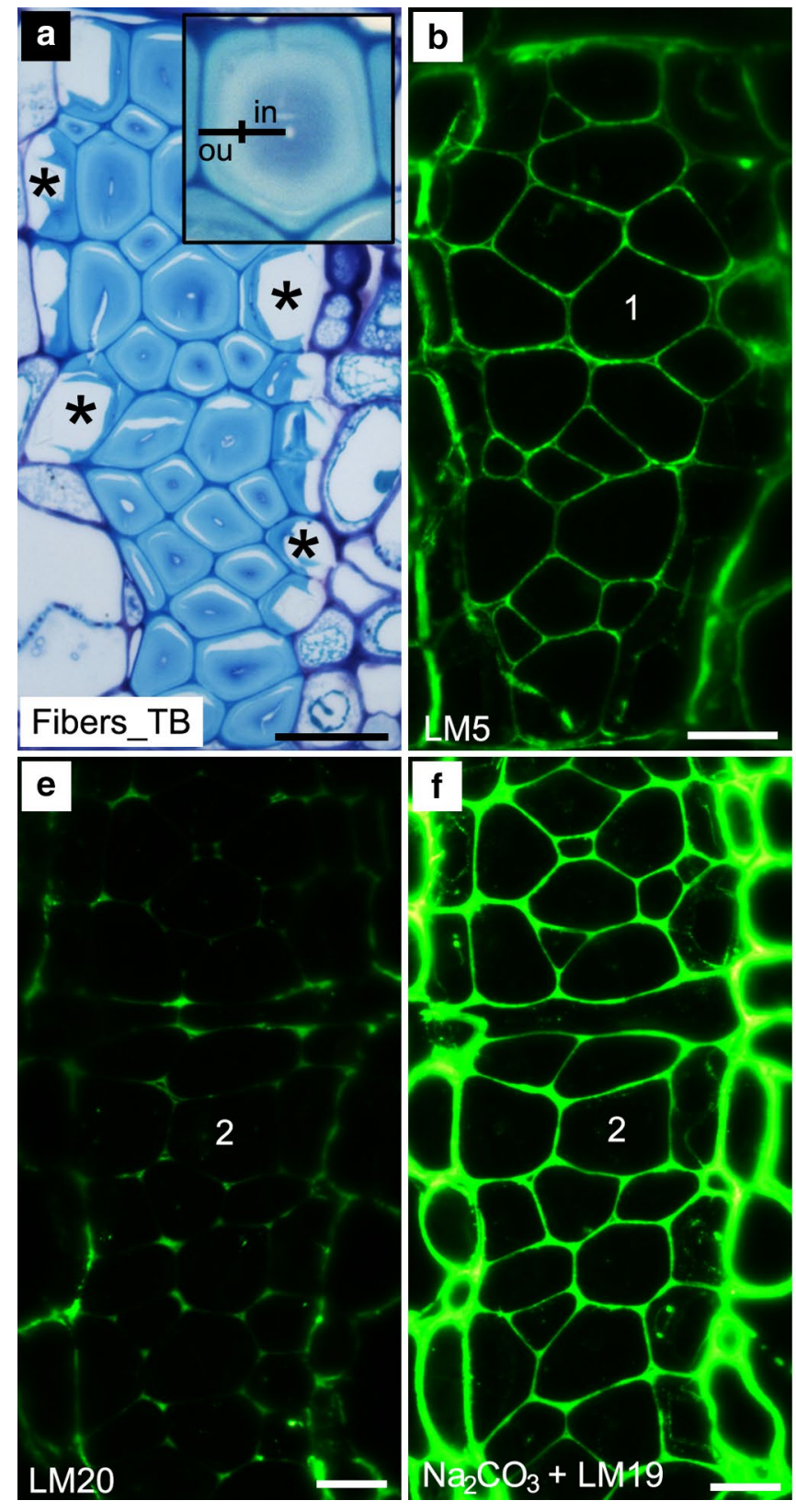

Fig. 12 Detection of pectin and hemicellulose epitopes in aspen phloem fibers. Numbers indicate the same cell. a Staining with toluidine blue (TB). Note different staining features between inner (in)and outer (ou) layers of secondary cell walls (inset). b, c Detection of LM5 (galactan) and LM6 (arabinan) epitopes showing considerable and sparse localization in CML. d, e Detection of LM19 (un-/ low methyl-esterified HG) and LM20 (highly methyl-esterified HG) epitopes showing sparse localization in CML. f Detection of LM19

indicates differences in the effect of HG masking or actual difference in composition of cell walls from ash SEs.

Results also show that pre-treatment of sections with sodium carbonate can increase the accessibility of LM19 antibody (Table 2; Fig. 4d). Pre-treatment of sections with alkali including sodium carbonate in this study is known

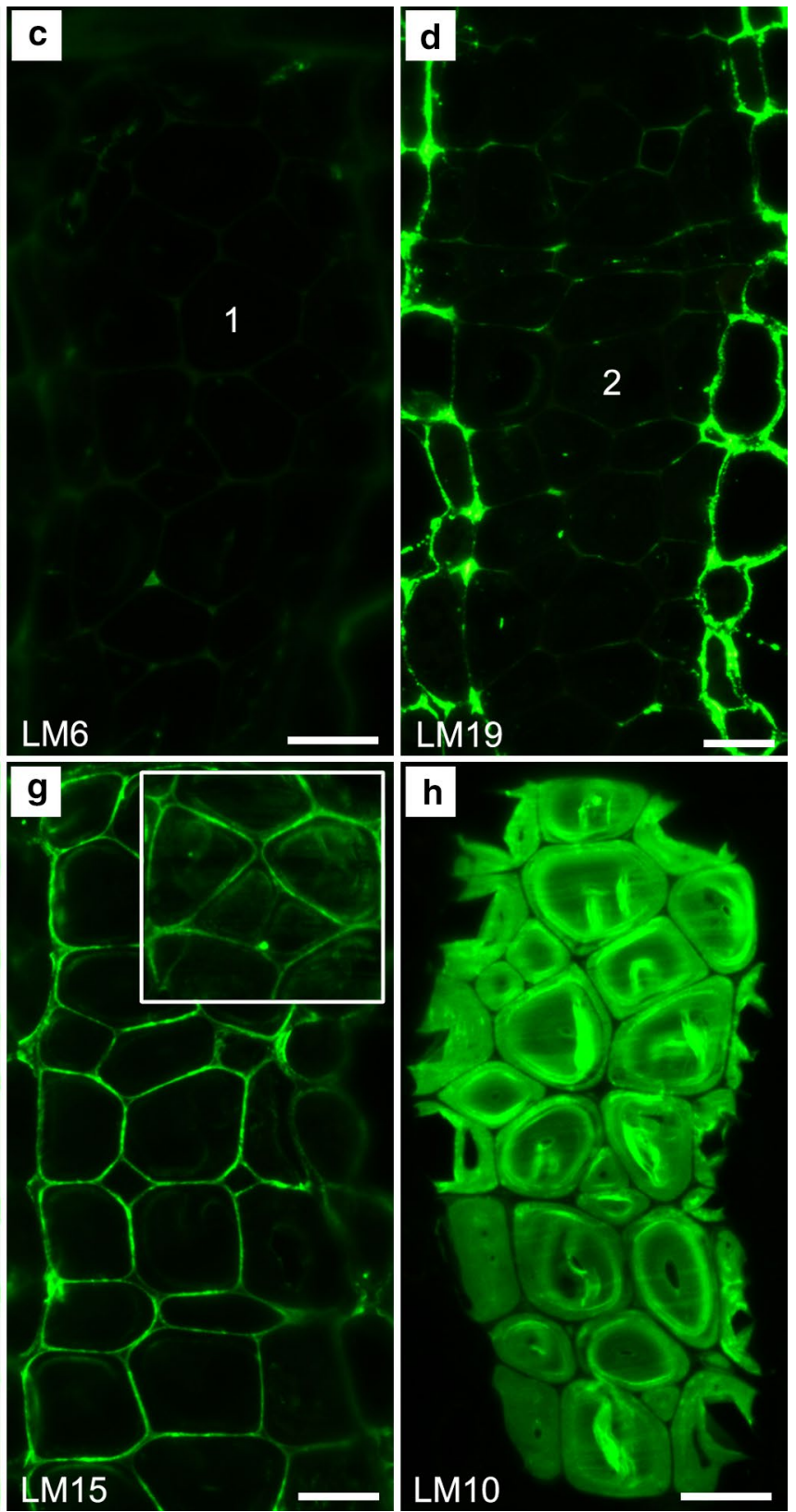

epitopes on sections pre-treated with sodium carbonate $\left(\mathrm{Na}_{2} \mathrm{CO}_{3}\right)$ showing significantly increased localization in CML compared to control (d). g Detection of LM15 (xyloglucan) epitopes showing considerable localization in CML. Note some sparse epitopes in secondary cell walls (inset). h Detection of LM10 (heteroxylan) epitopes showing abundant localization in secondary cell walls. Scale bars $25 \mu \mathrm{m}$

to remove methyl esters from HG (Davies and Urwin 2012; Marcus et al. 2010). This indicates that increase in the binding of LM19 antibody (binds to un-/low methylesterified HG) in phloem cells after pre-treatment of sections with sodium carbonate may mostly be due to removal of methyl esters from HG (Davies and Urwin 2012). The 
loss of binding of LM20 antibody (binds only to highly methyl-esterified HG) after pre-treatment may also confirm the effect of alkali pre-treatment for removal of methyl esters from HG. However, this explanation was not directly applicable to the thin CML of sclerenchyma cells (fibers and sclereids) that showed very sparse binding by both LM19 and LM20 antibodies, even though other cell types including SEs, CCs, parenchyma cells, and thick CML of sclerenchyma cells revealed binding by either one or both antibodies (Tables 1,2). The presence of HG in thin CML of sclerenchyma cells was precisely shown in only sections pre-treated with sodium carbonate by LM19 antibody. These results indicate that pre-treatment with sodium carbonate not only removed methyl esters from HG, but also excluded other unknown factors that may hinder access of antibodies to HG epitopes in thin CML of sclerenchyma cells. Results also emphasize the importance of alkali pre-treatment on detection of HG in sclerenchyma cells, since the result of localization of LM19/20 epitopes without pre-treatment can be quantitatively misinterpreted as absence or very little HG present in thin CML of sclerenchyma cells, even though abundant HG is actually present. A similar pre-treatment effect of sodium carbonate on detection of HG was also detected in stone cells of Norway spruce (softwood sclereids) (Kim and Daniel 2017).

\section{Heterogeneity in distributional patterns of pectin and hemicellulose epitopes in SEs, CCs, and parenchyma cells between hardwood species}

Results demonstrate that there is no clear correlation between distributional patterns of pectin and hemicellulose epitopes in SEs, CCs, and parenchyma cells and differences in xylem structure in terms of diffuse porous (birch and aspen)- and ring (oak and ash) porous hardwoods (Table 1). Instead, results indicate that there are great variations between the hardwood species studied, no matter their porous anatomy (Table 1).

Qualitatively (i.e., presence or absence of epitopes), SEs showed a clear difference between the hardwood species studied in relation with distribution of LM10 heteroxylan and LM21 heteromannan epitopes. LM10 epitopes were absent in aspen, but were present in the three other species, even though epitopes in birch SEs varied between SEs including their absence (Table 1). LM21 epitopes were only detected in ash SEs, specifically after removal of HG from SE cell walls (Table 1). Based on the general idea that the function of heteroxylans and heteromannans is related to the physical properties of wood cell walls, it can be expected that heteromannans and/or heteroxylans in SEs may contribute to strengthening of the SE cell wall and thus increase its suitability for long-distance transportation of assimilates in hardwood phloem. The absence of these two epitopes in
CCs and parenchyma cells (i.e., non-transporting cells) may support this hypothesis. However, at present, the reason for qualitative and quantitative differences in distributional patterns of these two structural polysaccharides in SEs between the hardwood species studied (i.e., aspen vs. birch vs. oak/ ash) remains unclear.

Results also showed several notable differences in the relative abundance of epitopes between the hardwood species studied. With respect to side chains of RG-I, difference in relative abundance of LM5 galactan and LM6 arabinan epitopes was overall smaller in aspen than the three other species. This result may reflect difference in the ratio of galactan and arabinan substitutions in RG-I between aspen (relatively similar between the two components) and the three other species (much richer in arabinan substitutions) (Figs. 1, 2; Table 1). However, there is also the possibility of difference in the amount of AGPs between birch and the other three species, since the LM6 antibody is known to bind to AGPs (Lee et al. 2005). With HG, LM19 (un-/low methyl-esterified HG) epitopes were much more abundant than LM20 (highly methyl-esterified HG) epitopes in oak SEs and parenchyma cells. In contrast, the three other species showed opposite patterns (Fig. 3; Table 1), indicating higher degree of HG methyl-esterification in SEs and parenchyma cells of oak. A notable difference in the amount of LM15 xyloglucan epitopes was also detected in oak SEs and birch parenchyma cells compared to the same cell type in the other three species (Fig. 5). The abundance of heteroxylan epitopes in SEs was also notably higher in oak and ash than birch.

Many studies have proposed that galactan and arabinanrich forms of RG-I contribute to increasing cell wall firmness and flexibility in plant cell walls, respectively (Lee et al. 2013; McCartney et al. 2000; Moore et al. 2013; Ulvskov et al. 2005; Verhertbruggen et al. 2009a, b). The pattern and degree of methyl-esterification also affect significantly the mechanical properties of plant cell walls, such as elasticity that is decreased with lower degree of methyl-esterification (Bidhendi and Geitmann 2016; Willats et al. 2001). Xyloglucans and heteroxylans are commonly related to strength of plant cell walls. These ideas suggest that variations in the structure and/or amounts of pectins and hemicelluloses as described above can lead to differences in mechanical properties of phloem cell walls between hardwood species.

\section{Heterogeneity in distributional patterns of pectin and hemicellulose epitopes in sclereids and phloem fibers between hardwood species}

Like primary wall cells (i.e., SEs, CCs and parenchyma cells), results of sclereids and phloem fibers (secondary cell wall) also indicate that there is no clear correlation between distributional patterns of pectin and hemicellulose epitopes 
between diffuse- and ring porous hardwoods (Table 2). For example, LM5 galactan epitopes were detected more readily than LM6 arabinan epitopes in aspen (diffuse) and oak (ring), whereas birch (diffuse) and ash (ring) showed overall opposite patterns (Table 2). Distributional patterns of pectin and hemicellulose epitopes in phloem fibers were also similar between diffuse porous (aspen)- and ring porous (oak) hardwoods (Table 2).

With respect to secondary cell walls, results show that there is no notable difference in the distributional patterns of pectin and hemicellulose in sclereids and phloem fibers between the hardwood species studied. LM10/11 heteroxylan epitopes were only detected in secondary cell walls of sclereids in all tree species (Table 2). Aspen and oak phloem fibers (phloem fibers were absence in birch and ash samples) also commonly showed abundant LM10/11 epitopes and sparse LM15 xyloglucan epitopes in some phloem fibers (Fig. 12g).

Considering CML (compound middle lamellae), results suggest that there are some variations in distributional patterns of pectin and hemicellulose in sclereids between the hardwood species studied. LM5 galactan epitopes in sclereids were much more abundant in aspen/oak (Fig. 10b, Supplemental Fig. 5b) than birch/ash (Fig. 8c, Supplemental Fig. 6b), indicating higher degree of galactan substitutions in RG-I in aspen/oak sclereids than birch/ash sclereids. With LM21 heteromannan epitopes, birch, aspen, and ash sclereids showed the presence of epitopes in CML, while oak sclereids revealed the absence of epitopes in CML (Table 2). As discussed above, these differences may contribute to differences in mechanical properties of sclereid CML, such as firmness, flexibility, and adhesion force between hardwood species, but further studies are required.

In contrast to sclereids, results demonstrate that there is no notable difference in the distribution of epitopes in CML of phloem fibers between aspen and oak. Overall, CML of phloem fibers showed similar distributional patterns of epitopes to CML of oak sclereids (i.e., presence of RG-I substituted highly with galactan, HG and xyloglucan epitopes, and absence of heteromannan epitopes). This similarity is likely related to similar anatomical structure of CML (i.e., thin CML) between phloem fibers and oak sclereids.

\section{Heterogeneity in distributional patterns of pectin and hemicellulose epitopes between cell types in hardwood phloem}

With respect to primary wall cells (i.e., SEs, CCs and axial/ ray parenchyma cells), results demonstrate that there are several differences in distributional patterns of pectin and hemicellulose epitopes between cells types in the same hardwood species. Except for aspen, the main qualitative difference between cell types was detected in the distribution of LM10 heteroxylan and LM21 heteromannan epitopes (i.e., presence in SEs and absence in CCs/parenchyma cells). Similar differences were also detected in the secondary phloem of softwood between sieve cells (i.e., similar functional cell to SEs, Evert 1977) and other parenchyma cells with distribution of LM21 epitopes. In Norway spruce and Scots pine phloem, LM21 epitopes were abundant in sieve cells but were absent in other parenchyma cells (Kim and Daniel 2017). These results suggest that the deposition of heteroxylans and/or heteromannans in the secondary phloem of tree stems only occurs in transporting cells. However, this does not explain the absence of these two epitopes in aspen SEs and some birch SEs.

Results also show there are several quantitative differences in distribution of pectin and xyloglucan epitopes between CCs and SEs in the same hardwood species. For example, SEs showed greater abundance of LM6 arabinan epitopes in aspen/ash, LM20 highly methyl-esterified HG epitopes in aspen/oak and LM15 xyloglucan epitopes in oak than CCs (Table 1). Together with the qualitative difference between the two cells as outlined above, these results indicate that the chemistry of SEs and CCs is differently regulated during cell development, since both cells are derived from the same cambial mother cell and undergo their own developmental process after unequal cell division from the cambial mother cell (Lalonde et al. 2001; van Bel 2003). It is proposed that the ratio of galactan and arabinan side chains in RG-I and the degree of methyl-esterification can affect the cell wall porosity/hydration and thus the movement of fluid (Bidhendi and Geitmann 2016; Larsen et al. 2011; Ulvskov et al. 2005; Willats et al. 2001). This may suggest that difference in the chemical structure of pectins between the two cell types may be related to the difference in the biological function between SEs (long-distance transport) and CCs (life maintenance of SEs). The notable difference in side chains of RG-I between SEs (richer in arabinans) and parenchyma cells (richer in galactans) in all hardwood species studied (Table 1) may also reflect the relationship between the chemistry of cell walls and physiological function of cells. For example, arabinan side chains hydrate more readily than galactan side chains in potato RG-I (Bidhendi and Geitmann 2016; Larsen et al. 2011). Several notable differences between CCs and parenchyma cells were also detected in the same hardwood species in relation with LM5/LM6, LM20, and LM15 epitopes, even though both cell types showed qualitatively similar distributional patterns of pectin and hemicellulose epitopes (i.e., presence of RG-I/HG/xyloglucan epitopes and absence of heteroxylan/ heteromannan epitopes) (Table 1).

Compared to primary wall cells, differences in distribution of pectin and hemicellulose epitopes between cell types (sclereids and phloem fibers) were less significant in secondary wall cells in aspen and oak. Both cell types showed 
abundant LM10/11 heteroxylan epitopes in secondary cell walls (Table 2). Since heteroxylans are a major hemicellulose contributing to strengthening of the secondary cell wall, it can be speculated that the abundance of heteroxylans in secondary cell walls of sclereids and phloem fibers is closely related to the biological role of the two cell types in hardwood phloem in a mechanical support (Zhao and Zhu 2014). The only difference in secondary cell walls between the two cell types was the presence of sparse LM15 xyloglucan epitopes in some phloem fibers. At present, we assumed that xyloglucan epitopes in some phloem fibers may be related to G-layer-like inner layers that were only detected in phloem fibers, but further studies are required. By the absence of LM21 heteromannan epitopes in secondary cell walls of sclereids and phloem fibers, we can also expect the chemistry of sclereids and phloem fibers differ from that of xylem fibers (i.e., sclerenchyma cells). Although heteromannans (ca. 2-5\%) are a minor hemicellulose type in hardwood xylem fibers, aspen and oak xylem fibers showed abundant LM21 epitopes in secondary cell walls (Kim and Daniel 2012a, 2016). With respect to sclereids, results further demonstrate that the chemistry of hardwood sclereids differs from softwood sclereids (stone cells) that showed abundant localization of both heteroxylan (LM10/LM11) and heteromannan (LM21/BGM C6) epitopes in secondary cell walls (Kim and Daniel 2017; Whitehill et al. 2015).

Differences in CML between sclereids and phloem fibers were detected in relation with distribution of LM21 heteromannan epitopes in aspen (i.e., presence and absence in sclereids and fibers, respectively) and LM10/11 heteroxylan epitopes in aspen/oak which were only sparsely detected in phloem fibers (Table 2). It is of interest that there are great variations in the chemistry of CML of sclereids depending on the anatomy of CML, specifically its thickness in the same hardwood species (birch or ash). Thicker CML revealed much more abundant LM6 arabinan, LM19 un-/low methyl-esterified HG and LM21 heteromannan epitopes than thinner CML (Table 2) in birch and ash sclereids. However, at present the reason for the difference in distributional patterns of epitopes depending on the anatomical structure of CML is unclear.

\section{Conclusions}

Immunolocalization of pectin and hemicellulose epitopes in phloem cells of four hardwood species demonstrates that there are great variations in distributional patterns of pectin and hemicellulose epitopes between cell types and between hardwood species. Results also indicate that there is no clear correlation between distributional patterns of pectin and hemicellulose epitopes in phloem and anatomical structure in xylem (i.e., diffuse- and ring porous hardwoods).
Observations of sclereids show there are great variations in distributional patterns of pectin and hemicellulose epitopes depending on anatomical structure of CML. Immunolocalization combined with alkali and enzyme pre-treatments confirm that detection of particular polysaccharide epitopes in hardwood phloem cells can be restricted by other cell wall components. Together, this study provides detailed basic chemical information of hardwood phloem at the individual cell wall level. This information can provide a basis for a better understanding of physiochemical functions of hardwood phloem. Findings in the study can also contribute to optimization of decomposition of hardwood phloem for various applications.

Author contribution statement JSK and GD conceived and designed the study. JSK performed the experiments. JSK and GD wrote the manuscript.

Acknowledgements The authors gratefully acknowledge funding provided by Formas projects 2008-1399, 2009-582, 2011-416, and 2015-469.

Conflict of interest The authors declare that they have no conflict of interest.

Open Access This article is distributed under the terms of the Creative Commons Attribution 4.0 International License (http://creativecommons.org/licenses/by/4.0/), which permits unrestricted use, distribution, and reproduction in any medium, provided you give appropriate credit to the original author(s) and the source, provide a link to the Creative Commons license, and indicate if changes were made.

\section{References}

Bidhendi AJ, Geitmann A (2016) Relating the mechanics of the primary plant cell wall to morphogenesis. J Exp Bot 67:449-4618. https://doi.org/10.1093/jxb/erv535

Bodîrlău R, Spiridon I, Teacă CA (2007) Chemical investigation of wood tree species in temperate forest in east-northern Romania. BioResources 2:41-57

Chaffey N, Barlow P (2001) The cytoskeleton facilitates a threedimensional symplasmic continuum in the long-lived ray and axial parenchyma cells of angiosperm trees. Planta 213:881823. https://doi.org/10.1007/s004250100560

Davies LJ, Urwin PE (2012) The cell walls of syncytia formed by Heterodera schachtii in Arabidopsis thaliana are abundant in methyl-esterified pectin. Plant Signal Behav 7:1404-1406. https://doi.org/10.4161/psb.21925

Donaldson LA (2001) Lignification and lignin topochemistry-an ultrastructural view. Phytochemistry 57:859-873. https://doi. org/10.1016/S0031-9422(01)00049-8

Dou J, Galvis L, Holopainen-Mantila U, Reza M, Tamminen T, Vuorinen T (2016) Morphology and overall chemical characterization of willow (Salix sp.) inner bark and wood: toward controlled deconstruction of willow biomass. ACS Sustain Chem Eng 4:3871-3876. https://doi.org/10.1021/acssuschemeng.6b00641 
Evert RF (1977) Phloem structure and histochemistry. Annu Rev Plant Physiol 28:199-222. https://doi.org/10.1146/annurev. pp.28.060177.001215

Eyles A, Jones W, Riedl K, Cipollini D, Schwartz S, Chan K, Herms DA, Bonello P (2007) Comparative phloem chemistry of Manchurian (Fraxinus mandshurica) and two North American ash species (Fraxinus americana and Fraxinus pennsylvanica). J Chem Ecol 33:1430-1448. https://doi.org/10.1007/s10886-007-9312-3

Fengel D, Grosser D (1975) Chemische Zusammensetzung von Nadelund Laubhölzern. Holz Roh-Werkst 33:32-34

Gričar J, Prislan P, De Luis M, Novak K, Longares LA, del Castillo EM, Čufar K (2016) Lack of annual periodicity in cambial production of phloem in trees from Mediterranean areas. IAWA J 37:349-364. https://doi.org/10.1163/22941932-20160138

Hernandez-Gomez MC, Runavot J-L, Guo X, Bourot S, Benians TAS, Villats WGT, Meulewaeter F, Knox JP (2015) Heteromannan and heteroxylan cell wall polysaccharides display different dynamics during the elongation and secondary cell wall deposition phases of cotton fiber cell development. Plant Cell Physiol 56:1786-1797. https://doi.org/10.1093/pcp/pcv101

Hervé C, Rogowski A, Gilbert HJ, Knox JP (2009) Enzymatic treatments reveal differential capacities for xylan recognition and degradation in primary and secondary plant cell walls. Plant $\mathbf{J}$ 58:413-422. https://doi.org/10.1111/j.1365-313X.2009.03785.x

IAWA Committee (1989) IAWA List of microscopic features for hardwood identification. IAWA Bull ns 10:219-332

Jones L, Seymour GB, Knox JP (1997) Localization of pectic galactan in tomato cell walls using a monoclonal antibody specific to $(1 \rightarrow 4)-\beta$-D-galactan. Plant Physiol 113:1405-1412. https://doi. org/10.1104/pp.113.4.1405

Kim JS, Daniel G (2012a) Distribution of glucomannans and xylans in poplar xylem and their changes under tension stress. Planta 236:35-50. https://doi.org/10.1007/s00425-012-1588-z

Kim JS, Daniel G (2012b) Immunolocalization of hemicelluloses in Arabidopsis thaliana stem. Part I: temporal and spatial distribution of xylans. Planta 236:1275-1288. https://doi.org/10.1007/ s00425-012-1686-y

Kim JS, Daniel G (2012c) Immunolocalization of hemicelluloses in Arabidopsis thaliana stem. Part II: Mannan deposition is regulated by phase of development and its patterns of temporal and spatial distribution differ between cell types. Planta 236:1367-1379. https://doi.org/10.1007/s00425-012-1687-x

Kim JS, Daniel G (2016) Variations in cell wall ultrastructure and chemistry in cell types of earlywood and latewood in English oak (Quercus robur). IAWA J 37:383-401. https://doi. org/10.1163/22941932-20160142

Kim JS, Daniel G (2017) Immunolocalization of pectin and hemicellulose epitopes in the phloem of Norway spruce and Scots pine. Trees 31:1335-1353. https://doi.org/10.1007/s00468-017-1552-4

Knox JP (2008) Revealing the structural and functional diversity of plant cell walls. Curr Opin Plant Biol 11:308-313. https://doi. org/10.1016/j.pbi.2008.03.001

Lalonde S, Franceschi VR, Frommer WB (2001) Companion cells. eLS. https://doi.org/10.1038/npg.els.0002087

Larsen FH, Byg I, Damager I, Diaz J, Engelsen SB, Ulvskov P (2011) Residue specific hydration of primary cell wall potato pectin identified by solid-state ${ }^{13} \mathrm{C}$ single-pulse MAS and CP/MAS NMR spectroscopy. Biomacromolecules 12:1844-1850. https://doi. org/10.1021/bm2001928

Lee KJ, Knox JP (2014) Resin embedding, sectioning, and immunocytochemical analysis of plant cell walls in hard tissues. Methods Mol Biol 1080:41-52. https://doi.org/10.1007/978-1-62703-643-6_3

Lee KJD, Sakata Y, Mau S-L, Pettolino F, Bacic A, Quatrano RS, Knight CD, Knox JP (2005) Arabinogalactan proteins are required for apical cell extension in the Moss Physcomitrella patens. Plant Cell 17:3051-3065. https://doi.org/10.1105/tpc.105.034413
Lee KJD, Marcus SE, Knox JP (2011) Cell wall biology: perspectives from cell wall imaging. Mol Plant 4:212-219. https://doi. org $/ 10.1093 / \mathrm{mp} / \mathrm{ssq} 075$

Lee KJD, Cornuault V, Manfield IW, Ralet M-C, Knox JP (2013) Multi-scale spatial heterogeneity of pectic rhamnogalacturonan I (RG-I) structural features in tobacco seed endosperm cell wall. Plant J 75:1018-1027. https://doi.org/10.1111/tpj.12263

Marcus SE, Verhertbruggen Y, Hervè C, Ordaz-Ortiz J, Farkas V, Pedersen HL, Willats WGT, Knox JP (2008) Pectic homogalactronan masks abundant sets of xyloglucan epitopes in plant cell walls. BMC Plant Biol 8:60. https://doi.org/10.1186/1471-2229-8-60

Marcus S, Blake AW, Benians TAS, Lee KJD, Poyser C, Donaldson L, Leroux O, Rogowski A, Petersen HL, Boraston A, Gilbert HJ, Willats WGT, Knox JP (2010) Restricted access of proteins to mannan polysaccharides in intact plant cell walls. Plant J 64:191203. https://doi.org/10.1111/j.1365-313X.2010.04319.x

McCartney L, Ormerod AP, Gidley MJ, Knox JP (2000) Temporal and spatial regulation of pectic $(1 \rightarrow 4)-\beta$-D-galactan in cell walls of developing pea cotyledons: implications for mechanical properties. Plant J 22:105-113. https://doi. org/10.1046/j.1365-313x.2000.00719.x

McCartney L, Marcus SE, Knox JP (2005) Monoclonal antibodies to plant cell wall xylans and arabinoxylans. J Histochem Cytochem 53:543-546. https://doi.org/10.1369/jhc.4B6578.2005

Moore JP, Nguema-Ona EE, Vicré-Gibouin M, Sørensen I, Willats WGT, Driouich A, Farrant JM (2013) Arabinose-rich polymers as an evolutionary strategy to plasticize resurrection plant cell walls against desiccation. Planta 237:739-754. https://doi.org/10.1007/ s00425-012-1785-9

Nanko H, Côté WA (1980) Bark structure of hardwoods grown on southern pine sites. Syracuse University press, New York

Pettersen RC (1984) The chemical composition of wood. In: Rowell R (ed) The chemistry of solid wood. American Chemical Society, Washington DC, pp 57-127

Savage JA, Clearwater MJ, Haines DF, Klein T, Mencuccini M, Sevanto S, Turgeon R, Zhang C (2016) Allocation, stress tolerance and carbon transport in plants: how does phloem physiology affect plant ecology?. Plant Cell Environ 39:709-725. https://doi. org/10.1111/pce.12602

Şen A, Miranda I, Santos S, Graça J, Pereira H (2010) The chemical composition of cork and phloem in the rhytidome of Quercus cerris bark. Ind Crops Prod 31:417-422. https://doi.org/10.1016/j. indcrop.2010.01.002

Thornber JP, Northcote DH (1961) Changes in the chemical composition of a cambial cell during its differentiation into xylem and phloem tissue in trees. 2. Carbohydrate constituents of each main component. Biochem J 81:455-464

Ulvskov P, Wium H, Bruce D, Jørgensen B, Qvist KB, Skjøt M, Hepworth D, Borkhardt B, Sørensen SO (2005) Biophysical consequences of remodeling the neutral side chains of rhamnogalacturonan I in tubers of transgenic potatoes. Planta 220:609-620. https://doi.org/10.1007/s00425-004-1373-8

van Bel AJE (2003) The phloem, a miracle of ingenuity. Plant cell Environ 26:125-149. https://doi. org/10.1046/j.1365-3040.2003.00963.x

Verhertbruggen Y, Marcus SE, Haeger A, Ordaz-Ortiz JJ, Knox JP (2009a) An extended set of monoclonal antibodies to pectic homogalacturonan. Carbohydr Res 344:1858-1862. https://doi. org/10.1016/j.carres.2008.11.010

Verhertbruggen Y, Marcus SE, Haeger A, Verhoef R, Schols HA, McCleary BV, McKee L, Gilbert HJ, Knox JP (2009b) Developmental complexity of arabinan polysaccharides and their processing in plant cell walls. Plant J 59:413-425. https://doi. org/10.1111/j.1365-313X.2009.03876.x

Whitehill JG, Henderson H, Schuetz M, skyba O, Yuen MMS, King J, Samuels AL, Mansfield SD, Bohlmann J (2015) Histology and 
cell wall biochemistry of stone cells in the physical defense of conifers against insects. Plant Cell Environ 39:1646-1661. https:// doi.org/10.1111/pce.12654

Willats WGT, Marcus SE, Knox JP (1998) Generation of monoclonal antibody specific to $(1 \rightarrow 5)-\alpha$-L-arabinan. Carbohydr Res 308:149-152

Willats WGT, Orfila C, Limberg G, Buchholt HC, van Ale-beek G-JWM, Voragen AGJ, Marcus SE, Christensen TMIE, Mikkelsen JD, Murray BS, Knox JP (2001) Modulation of the degree and pattern of methyl-esterification of pectic homogalacturonan in plant cell walls: implications for pectin methyl esterase action, matrix properties and cell adhesion. J Biol Chem 276:1940419413. https://doi.org/10.1023/A:1010662911148

Xue J, Bosch M, Knox JP (2013) Heterogeneity and glycan masking of cell wall microstructures in the stems of Miscanthus $\times$ giganteus and its parents M. sinensis and M. sacchariflorus. PLoS One 8:e82114. https://doi.org/10.1371/journal.pone.0082114

Zhao M, Zhu H (2014) Development and morphology of stone cells in phloem of Toxicodendron vernicifluum. Trees 28:1553-1558. https://doi.org/10.1007/s00468-014-1027-9 